\title{
Cross program for weighting to develop the functional strength of the center muscles and its effect on the strength of the two side-flip skills from (Waist Turnover \& High Waist Turnover) for Wrestlers
}

\section{*Dr. Belal Morsy Mohammed Witwit}

Introduction and research problem

The objective of the training process is to reach the best ways to improve the level of achievement of the player as the achievement is considered to be the focus of attention in the training process.

Mohamed Sobhi Hassanein and Ahmed Kasrai Maani (1998) point that muscle strength is one of the most important components of fitness. The performance of most sports activities depends on it and the availability of it is a necessity to reach the individual to the highest ranks of the championship in many sports. It is the basis in physical performance, if it is not the basis, then it will not be Less than the most important supports on which movement and sports practice depend, and this requirement is important and necessary for many sports activities especially power activities such as wrestling. (38: 22.17)

Adel Abdul Basir
(1999) emphasizes that great
muscle power has its impact
and importance in the types of
sports activities that require
overcoming resistance such as
wrestling in force movements
such as fixed positions, lifting
movements, reduction
movements, in addition to its
importance when associated
with high constriction speed or
requirements for endurance.
(2:98)

According to Essam Abdul Khaleq (2003), muscle strength is one of the most important physical and motor abilities that affect the performance level in sports activities. Muscle strength is considered to be the most basic ability in all forms of sports activity. In each kind of sports activity physical performance is always against different resistances as in wrestling,

"Assistant Professor at the Department of fighting \& individual sports' theories and application in the faculty of physical education - Menoufia university.

Assiut Journal For Sport Science Arts 
wrestling player has to overcome his opponent.

(18: 129)

Salah Asseran (1996) points out that muscle strength is one of the most important requirements of the sport of wrestling due to the nature of the performance and the multiplicity of resistances faced by the wrestler. Where he defines it as the ability of the wrestler to capture, lift, push, draw and throw during the execution of offensive and defensive movements and counterattack. (50)

The training methods used in the development of strength are multiplied according to the nature of skill or requirements for sports effectiveness and weightlifting training is the most important means of developing muscle strength, which has a significant impact in improving the level of many sporting events.

(10: 124)

Ali Saeed Rehan (1994) points out that weightlifting training is considered as an objective means of developing the different types of muscle strength that the wrestler so desperately needs and plays a key role in raising the effectiveness of the professional performance of the wrestler in general and strengthening the lifting movements in particular. He also mentions, quoting German and Hanley, the wrestler needs to have high levels of muscle strength so he can perform lifting skills appropriately and efficiently. [6]

\section{Westcott}

(1995)

suggests that the weightlifting training program differs from conventional weight-bearing programs, as there is a potential for increased resistance in weightlifting training, which effectively affects the development of muscle strength. (59: 3)

\section{Massad Ali Mahmoud} et al (1998) emphasize that weightlifting training is an objective means of developing the different types of muscle strength that a wrestler needs and plays a fundamental and essential role in increasing the efficiency of the skillful performance of the wrestler in general and strengthening the lifting movements in particular. (40:77)

Talha Hossam El-Din et al. (1997) point out those 
weightlifting trainings is numerous and various. It helps to develop muscular strength, speed and endurance, as well as muscle tone, help avoid injury, help muscles maintain their functions at the advanced age. Weightlifting training must be performed in the same settings as the player in the performance of specialized sports skills $(52: 15,36)$

$\begin{array}{lrr}2 & \text { Bastweissi } & \text { Ahmed } \\ \text { (1999) confirms } & \text { that }\end{array}$ weightlifting trainings occupies a privileged position in most sports activities and was adopted by most coaches as an effective means in the development of strength for the player and weightlifting training has become an important role in training programs aimed at preparing players in various sports activities. (10:130)

Zaki Mohammed Mohammed Hassan (2004), Mohammed Jaber Berriq, Ihab Fawzi Al-Badiwa (2004) point out that muscle strength of all kinds is the main basis for cross training activities for most sports activities, especially activities that depend on muscle strength, speed and movements. Explosive as wrestling. (61:17) (34:36)

They also emphasize that cross training is a tool or a means of training to help the player reach the highest level of competition in his or her specialized sport (61: 14) (34: 5)

According to Abdul Aziz al-Nimr, Nariman Al Khatib (2005) performance improves better if the training is specific to the type of activity practiced and includes the most important muscles involved in this activity and its development in the same way as it is used in competition. (1: 188)

To improve the performance and increase the efficiency of the achievement, it is necessary to design exercises according to the model of movement used in the competition, in terms of body position and the extent of movement and contractions prevailing for working muscle groups.

In the wrestling match, the wrestler uses all kinds of power. In the skills of lifting, grabbing and pushing, the wrestler needs maximum 
muscle strength. During the abduction, the attack and the counterattack require explosive force and speed. The repetition of the performance of skills and motor sentences and the continuation of the conflict efficiently and effectively until the end of the game time needs to endure the force.

It is clear the importance of muscle strength in wrestling skills as a skill of the side flip of the bottom and from the top of the high bridge, which is one of the most used and effective skills and score points in the games, which the law has given special importance. Where the opponent is obliged to put the ground in a negative situation and from this situation is the implementation of the two skills is more than the implementation of other skills.

\footnotetext{
Amal Mohammed Mousa (2005) states that functional strength training is an important exercise that helps to develop the muscle strength of the muscles of the center, which is represented by the muscles of the abdomen and back. And this is one of the most important features of functional strength training,
}

which is the focus on the muscle group of the center. (8:3)

Wesam Sami (2016) demonstrates that functional strength training helps to develop the muscular strength of the center area because it contains exercises that help strengthen the abdominal and back muscles. The strong center muscles transfer the movement from the lower limb to the upper limb and prevent the leakage of force. It also works to strike a balance between the two sides and the imbalance in the center area will affect the skill and physical performance. [58]

Tiana Weiss et al (2010) point out that functional strength training is one of the most recently used methods in the development of muscle strength and that it can contribute as a way to improve technical performance that is similar to the shape and nature of performance with a focus on the full motor range of motion. (55)

Michael Boyle (2004) emphasizes that functional strength training programs must contain a combination of strength and balance training 
scoring

including

stabilization and deceleration,

with the aim of improving motor ability and central strength, whose performance requires maximum integration of strength of muscles with maximum performance speed to achieve a high degree of performance ability.(32:264)

Dave Schmitz (2003) indicates that functional strength training is characterized by characteristics and features, the most important of which is the focus on the center muscle group, which helps to connect the lower limb to the upper limb, namely the abdominal muscles, the muscles of the spine and the muscles of the sides. In addition to preventing the leakage of force, and the multiplicity of Levels i.e. the performance of sports movements in more than one direction and not limiting the exercise to one direction only, and the multiplicity of joints training should focus on the use of more than one joint instead of one joint. And control the counterbalance Multidirectional movements require balance, and here requires not only strong muscles of the center but Sufficient skill and compatibility of performance, the use of all parties in a rotational manner, and the integrative movement as functional training aims to increase the sensitivity and integration of the body, and qualitative activity. To achieve this, we need to understand the nature and requirements of the sport activity and by understanding the performance requirements to determine the exercises and resistances to meet those needs, and the specific speed of the activity. (14: 3-5)

\section{Mohammed}

alAshmawi (2003), quoting $\mathrm{J}$. Jesse, states that the outstanding wrestler is a person of high level of strength and requires special types of strength to focus on certain areas of the body. (34)

In the opinion of Elsayed. Abdel-Maqsoud (1997), Mohamed Elawi (1994), that special force training is similar in its kinetic composition in terms of force, time, and motion curve with the movements performed during the competition and 
based on the same muscle groups (17: 224) (36: 103)

\section{Mohammed Ashmawy}

(2003) states that the skill of the side-flip is one of the best and most effective skills of putting the conflict in the land of Roman wrestling as it is one of the technical movements that can be obtained from the highest technical points. It can be said that the player who mastered those skills can overcome the defenses of any competitor, whatever his level of physical and skill preparation. (34)

\section{Magdy Aliuah (1998),} Ali Rehan (1994), Mus'ad Ali Mahmoud et al. (1995) found that lifting skills to the top as a side flipping skill from a top of a high bridge means lifting the opponent up from the surface of the rug to lose the base of his balance and ability to defend and counterattack. (29) (6) (40: 43)

\section{Salah Mohammed}

Asran (1996) states that the lifting movements in Roman wrestling such side flipping skill from a top of a high bridge, which are performed from the position of the conflict from the bottom is considered one of the most important movements that can play a large role in collecting the largest number of points and ending the game for the sake of the wrestler who is good at this type of movement. As the implementation of these movements, make the opponent lose the contact to ground. And then lose control and balance and the ability to defend and when lifting the opponent should be as close to the line of weight of the body of the wrestler during the lift to reduce the outer momentum and must catch on the opponent well and attached to the trunk to approximate the center of gravity.(50)

\section{Ali al-Saeed Rihan} (1994), quoting Al-Saeed Nada and Mohammed AlKilani, assured that the wrestler must build his strength to a level beyond the normal requirements of the match so that lifting skills can be easily performed during the conflict. He also states that the wrestler needs the different types of muscular strength as the conflict is characterized by high degrees of strength to overcome violent and persistent resistance during the conflict. [6] 
With the development of wrestling, its requirements have increased from the special strength associated with the skill performance and is trained with special training related to the skilled performance of wrestling skills where the wrestler needs it to a high degree in order to be able to perform its various skills.

\section{Musa Fahmy, Adel Ali} (1994) points out that the purpose of the exercises developed is to prepare certain muscle groups to suit the skills of the type of activity, i.e. they work to develop the muscles working in skill with attention to the technical aspects side by side and these exercises are often difficult and complex (39:93)

\section{(2003) and Alaa Kanawi (1996) point out that in order} for the wrestler to perform skills effectively in matches; this requires special preparations that include the physical side linked to the skilled side. (34) (4)

\section{Elsayed}

Abdel

Maksoud (1997) explains that simulation exercises, which are considered like technique exercises, should be used only for parts of skills, such as those with key functional stages. (17: 324)

The problem of research crystallizes in that through the practice of the researcher of the sport of wrestling as a player and then a coach found a lack of skilled performance of the skills of the side flip from the bottom and from the top of the high bridge. And its failure to perform in the correct technical form in terms of the inability to flip and raise the competitor by pushing the pelvis up by the bridge either from the bottom or from the top which leads to the failure of skill and the loss of opportunity the player had to win. And also not performing it in an ideal way allows the player to get the full points due to the weakness of the muscles of the center in the middle of the body represented by the muscles of the abdomen and back. As well as ways and methods of the training used that does not take into account the muscles working in the performance of the skills as well as the correct technical dynamic track of skill. Mohammad Reda Al-Roubi (2005) asserts that the set of lifting This group is 
characterized by the loss of the opponent contact the ground and then loses control in his skills and thus loses his ability to defend so it is easy for the striker to carry out his chosen skills. Skills up is an important skill for all wrestlers. (37:52)

\section{Wassal Abdelwahed} Kortam (2014)(57) analyze the London Olympics (2012) that the most effective and point scoring skills of conflict mode from the bottom is skill (waist rotation from bottom).

The researcher called for the design of a cross-sectional program using weights for functional strength, which will develop the muscular strength of the center region, which is similar in technique to performance with the performance of the skills of flipping down and up.

\section{Research goals:}

The aim of this research is to design a weight-training program using the crossfunctional method of the functional muscles of the center and to identify its effect on:

Strength variables for the performance of the skill (the side flip from the bottom) and the (side flip from the top with a high bridge) for the wrestlers.

\section{Research hypotheses :}

There were statistically significant differences between the (the previous and next) indices of the experimental and control groups in the strength variables for the skill performance (side flip from bottom) and the side flip from the top of the high bridge for the wrestlers in the direction of the next telemetry.

There were statistically significant differences between the two next indices of the two groups (experimental and control) in the strength variables for the performance of the skills (side flip from the bottom) and the side flip from the top with a high bridge for the wrestlers of the control group.

\section{Search terms}

\section{Cross training}

It is the use of a different activity or training technique or sport other than the main activity or sport of the player to help improve performance in the main activity or sport $(26: 17)(35: 4)$

\section{Functional strength training}

Is an integrated and multi-level movements aimed at improving 
motor abilities, central strength, functional and muscular efficiency. (9)

\section{Center muscles}

It means the muscles of the middle of the body, which cause the erection of the individual strength and are the muscles of the abdomen and muscles of the spine and muscles of the sides. (Procedural definition) Side flipping from the bottom

It is one of the skills of wrestling sport, which is performed from the situation of the conflict from the bottom and the wrestler encircling the waist of his opponent with arms from the back and try to turn around the long axis by putting the bridge to access the primary situation (11).

\section{Side flipping from the top}

Is one of the skills of wrestling sport, which is performed from the situation of the conflict from the bottom and the wrestler encircling the waist of his opponent with the arms from the back and then lift up and then curving and high side flip of the high bridge around the longitudinal axis. (Procedural definition)
Search procedures

Methodology

The researcher used the experimental method because of its relevance to the nature of the research, using the experimental design of the previous and the following measurement on the two groups (experimental and control).

\section{Research sample}

The sample of the research was selected in the deliberate manner of the players of the Team of the Region of Menofia (fourth stage) season (2018 - 2019) and registered with the Egyptian Wrestling Federation. Where the research community reached (30. Wrestlers were selected (10) wrestlers to conduct exploratory studies on them, and thus the basic study was applied On (20) wrestlers were divided into two equal groups, one experimental and the other controlled by (10) wrestlers per group, and a table (1) showing the homogeneity of the research sample in variables (growth - physical variables).

Table (1) 
Homogeneity of the research sample in variables (growth physical variables) $\mathbf{n}=\mathbf{3 0}$

\begin{tabular}{|c|c|c|c|c|c|c|c|}
\hline \multicolumn{3}{|c|}{ Variables } & Unit & Mean & Median & $\begin{array}{l}\text { St.Div } \\
\end{array}$ & Skewness \\
\hline \multirow{4}{*}{\multicolumn{2}{|c|}{ 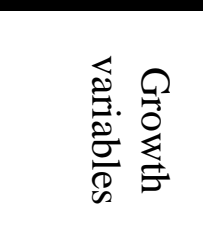 }} & Age & Year & 22.8 & 21.5 & 3.585 & 0.14 \\
\hline & & Length & $\mathrm{Cm}$ & 174.8 & 176 & 5.067 & 0.54 \\
\hline & & The weight & $\mathrm{Kg}$ & 82.8 & 80 & 10.06 & 0.49 \\
\hline & & The training age & Year & 11.53 & 10.5 & 2.75 & 0.23 \\
\hline \multirow{4}{*}{\multicolumn{2}{|c|}{ 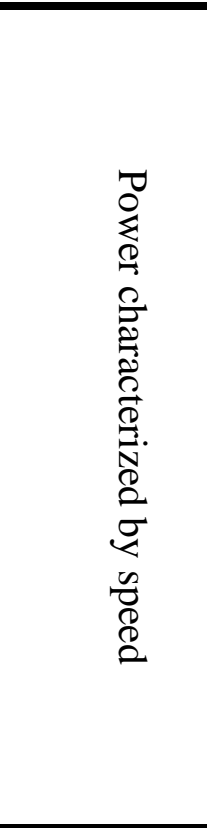 }} & $\begin{array}{c}\text { Time of } 3 \\
\text { high rolls } \\
\text { with dummy }\end{array}$ & Second & 7.016 & 7.15 & 0.421 & 0.57 \\
\hline & & $\begin{array}{l}\text { Time of } 4 \\
\text { rolls of the } \\
\text { waist from } \\
\text { the bottom } \\
\text { with dummy }\end{array}$ & Second & 5.409 & 8.305 & 0.351 & 1.37 \\
\hline & & $\begin{array}{l}\text { Time of } 8 \\
\text { lifts with a } \\
\text { high roll of } \\
\text { the lifting } \\
\text { device from } \\
\text { the bottom }\end{array}$ & Second & 12.7 & 12.68 & 0.144 & 0.32 \\
\hline & & $\begin{array}{l}\text { Time of } 8 \\
\text { waist rolls } \\
\text { from the } \\
\text { bottom with } \\
\text { the use of the } \\
\text { device of pull } \\
\text { weights from } \\
\text { the bottom }\end{array}$ & Second & 17.669 & 17.665 & 0.199 & 0.86 \\
\hline \multirow{2}{*}{\multicolumn{2}{|c|}{$\begin{array}{l}\text { Explosive } \\
\text { force }\end{array}$}} & $\begin{array}{l}\text { Roll the waist by } \\
\text { the fellow from } \\
\text { the bottom }\end{array}$ & Second & 1.742 & 1.735 & 0.275 & 0.68 \\
\hline & & $\begin{array}{l}\text { Roll the waist } \\
\text { by the fellow } \\
\text { from the top }\end{array}$ & Second & 2.339 & 2.34 & 0.14 & 0.57 \\
\hline 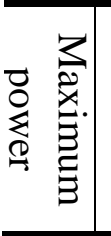 & 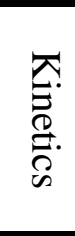 & $\begin{array}{l}\text { The maximum } \\
\text { kinetic force of } \\
\text { the high grip } \\
\text { roll of the } \\
\text { weightlifting } \\
\text { device from the } \\
\text { bottom }\end{array}$ & $\mathrm{Kg}$ & 151 & 150 & 7.588 & 0.43 \\
\hline
\end{tabular}

Follow Table (1) 
Homogeneity of the research sample in variables (growth physical variables) $\mathbf{n}=\mathbf{3 0}$

\begin{tabular}{|c|c|c|c|c|c|c|}
\hline \multicolumn{2}{|c|}{ Variables } & Unit & Mean & Median & St.Div & Skewness \\
\hline & $\begin{array}{l}\text { The maximum } \\
\text { kinetic force of } \\
\text { the waist grip } \\
\text { roll of the } \\
\text { weightlifting } \\
\text { device from the } \\
\text { bottom }\end{array}$ & $\mathrm{Kg}$ & 115.33 & 115 & 7.42 & 0.53 \\
\hline & $\begin{array}{l}\text { The maximum } \\
\text { kinetic force of } \\
\text { straight } \\
\text { abdominal } \\
\text { muscles with } \\
\text { torso drape }\end{array}$ & $\mathrm{Lb}$ & 54.166 & 55 & 3.238 & 0.39 \\
\hline & $\begin{array}{l}\text { The maximum } \\
\text { kinetic force of } \\
\text { the right } \\
\text { oblique } \\
\text { abdominal } \\
\text { muscles of the } \\
\text { weights to bend } \\
\text { the torso }\end{array}$ & $\mathrm{Lb}$ & 42.333 & 45 & 1.625 & 0.04 \\
\hline & $\begin{array}{l}\text { The maximum } \\
\text { kinetic force of } \\
\text { the left oblique } \\
\text { abdominal } \\
\text { muscles of the } \\
\text { weights to bend } \\
\text { the torso }\end{array}$ & $\mathrm{Lb}$ & 38.066 & 40 & 0.907 & 0.44 \\
\hline & $\begin{array}{l}\text { The maximum } \\
\text { kinetic force of } \\
\text { the back } \\
\text { muscles with } \\
\text { the weights } \\
\text { material for the } \\
\text { back }\end{array}$ & $\mathrm{Lb}$ & 65.333 & 65 & 2.604 & 0.02 \\
\hline$\triangleq$ & $\begin{array}{l}\text { The fixed } \\
\text { maximum lift } \\
\text { force of the } \\
\text { high roll }\end{array}$ & $\mathrm{Kg}$ & 141.83 & 145 & 5.645 & 0.49 \\
\hline 泀市 & $\begin{array}{l}\text { The maximum } \\
\text { fixed strength } \\
\text { of the waist roll }\end{array}$ & $\mathrm{Kg}$ & 71.666 & 67 & 22.75 & 0.65 \\
\hline$\vec{Q} \vec{\sigma}$ & $\begin{array}{l}\text { the strength } \\
\text { of the back } \\
\text { muscles }\end{array}$ & $\mathrm{Kg}$ & 160.33 & 165 & 19.26 & 0.5 \\
\hline
\end{tabular}

Follow Table (1) 
40

Homogeneity of the research sample in variables (growth physical variables) $\quad \mathbf{n}=\mathbf{3 0}$

\begin{tabular}{c|c|c|c|c|c|c}
\hline \hline \multicolumn{2}{c|}{ Variables } & Unit & Mean & Median & St.Div & Skewness \\
\hline \hline \multirow{2}{*}{} & $\begin{array}{c}\text { the strength } \\
\text { of the 2 leg } \\
\text { muscles }\end{array}$ & $\mathrm{Kg}$ & 256.1 & 254 & 13.52 & 0.92 \\
\cline { 2 - 7 } & $\begin{array}{c}\text { right fist } \\
\text { using the } \\
\text { manometer. }\end{array}$ & $\mathrm{Lb}$ & 120.6 & 121 & 5.757 & 0.09 \\
\cline { 2 - 8 } & $\begin{array}{c}\text { left fist using } \\
\text { the manometer. }\end{array}$ & $\mathrm{Lb}$ & 122.87 & 121 & 5.393 & 0.43 \\
\hline \multirow{2}{*}{ strength } & $\begin{array}{c}\text { high rolls } \\
\text { Eith dummy }\end{array}$ & Repetition & 17.6 & 18 & 1.631 & 0.42 \\
\cline { 2 - 8 } & $\begin{array}{c}\text { bottom rolls } \\
\text { with dummy }\end{array}$ & Repetition & 41.366 & 40.5 & 3.398 & 0.38 \\
\hline Balance & Fixes & Second & 21.567 & 21.2 & 1.173 & 0.73 \\
\cline { 2 - 8 } & Kinetic & Degree & 4.567 & 5 & 0.504 & 0.28 \\
\hline \multirow{2}{*}{ Flexibility } & Horizontal & Cm & 43.366 & 42 & 10.51 & 0.53 \\
\cline { 2 - 8 } & Vertical & Cm & 46.33 & 46 & 2.822 & 0.17 \\
\hline \hline
\end{tabular}

It is clear from Table (1) that the torsion coefficient in the growth and physical variables was limited to $(-3,+3)$ indicating the homogeneity of the research sample in these variables.

- Equality of the two research groups

Table (2)

Arithmetical mean, standard deviation and value (T) And their significance in the variables (growth - physical) of the groups (experimental / control) $\quad \mathrm{N} 1=\mathrm{N} 2=10$

\begin{tabular}{|c|c|c|c|c|c|c|}
\hline \multirow{2}{*}{\multicolumn{2}{|c|}{ Variables }} & \multicolumn{2}{|c|}{$\begin{array}{l}\text { Experimental } \\
\text { Group }(n=10)\end{array}$} & \multicolumn{2}{|c|}{$\begin{array}{c}\text { Control } \\
\text { Group }(n=10)\end{array}$} & \multirow[t]{2}{*}{$\mathbf{T}$} \\
\hline & & Mean & St.Div & Mean & St.Div & \\
\hline \multirow{4}{*}{ 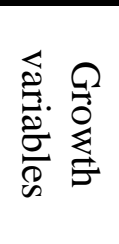 } & Age & 22.6 & 3.717 & 22 & 3.399 & 0.38 \\
\hline & Length & 175.8 & 3.583 & 173.6 & 5.481 & 1.06 \\
\hline & The weight & 86 & 13.06 & 80 & 7.125 & 1.25 \\
\hline & The training age & 11.5 & 2.99 & 10.7 & 2.406 & 0.66 \\
\hline
\end{tabular}

Follow Table (2) 


\section{Arithmetical mean, standard deviation and value (T) And their significance in the variables (growth - physical) of the groups (experimental $/$ control) $\quad \mathrm{N} 1=\mathrm{N} 2=10$}

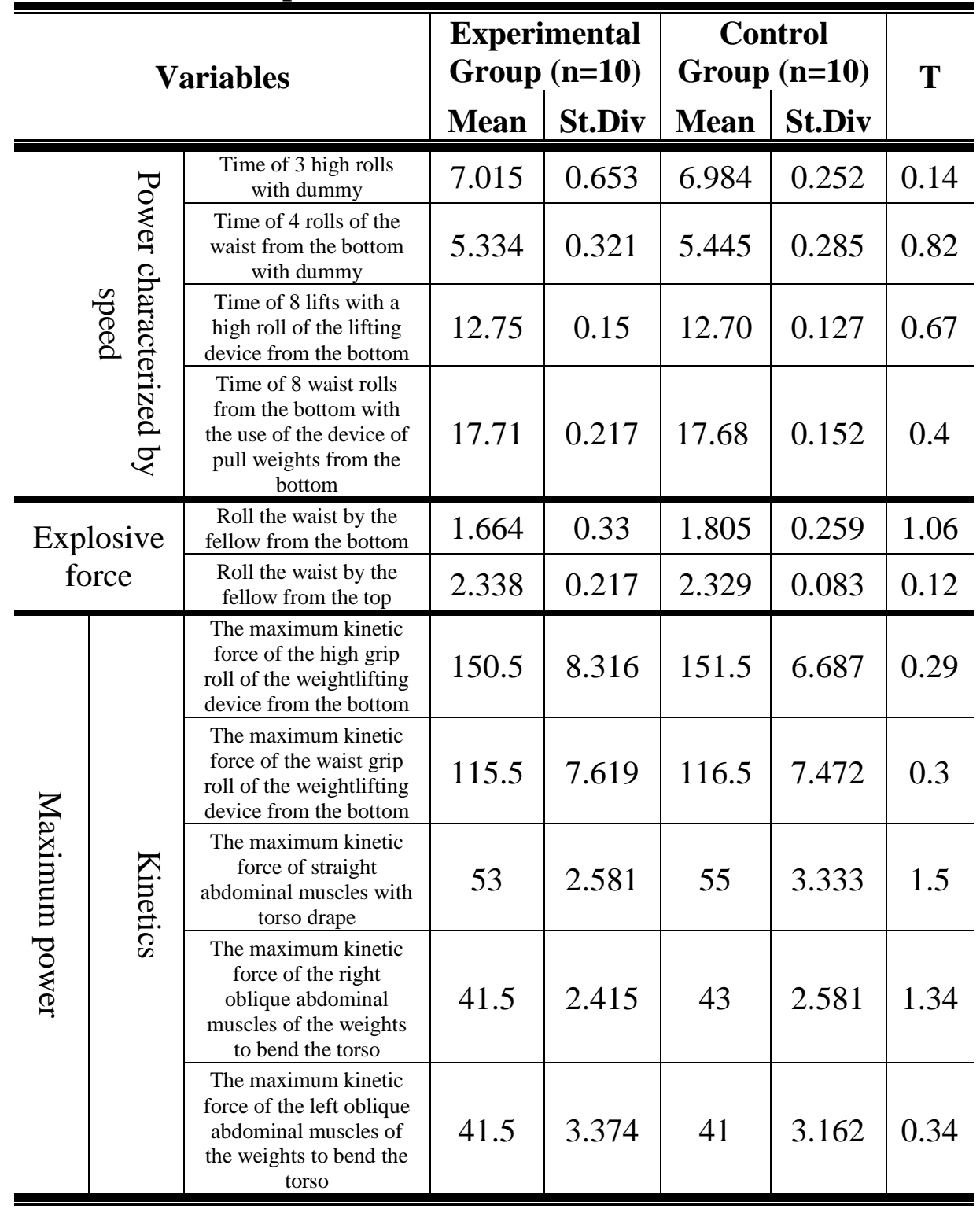

Follow Table (2) 


\section{Arithmetical mean, standard deviation and value (T) And their significance in the variables (growth - physical) of the groups (experimental / control) $\mathrm{N} 1=\mathrm{N} 2=10$}

\begin{tabular}{|c|c|c|c|c|c|c|}
\hline \multirow{2}{*}{\multicolumn{2}{|c|}{ Variables }} & \multicolumn{2}{|c|}{$\begin{array}{l}\text { Experimental } \\
\text { Group }(n=10)\end{array}$} & \multicolumn{2}{|c|}{$\begin{array}{c}\text { Control } \\
\text { Group }(n=10)\end{array}$} & \multirow[t]{2}{*}{$\mathbf{T}$} \\
\hline & & Mean & St.Div & Mean & St.Div & \\
\hline \multirow{7}{*}{ 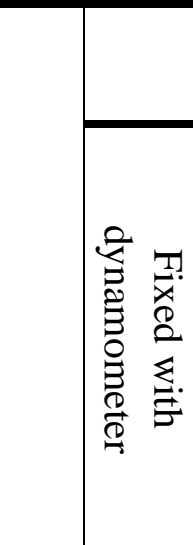 } & $\begin{array}{l}\text { The maximum kinetic force } \\
\text { of the back muscles with } \\
\text { the weights material for the } \\
\text { back }\end{array}$ & 66 & 3.944 & 66 & 3.162 & 0 \\
\hline & $\begin{array}{l}\text { The fixed maximum lift } \\
\text { force of the high roll }\end{array}$ & 139 & 6.582 & 143 & 4.216 & 1.62 \\
\hline & $\begin{array}{l}\text { The maximum fixed } \\
\text { strength of the waist roll }\end{array}$ & 70.3 & 21.03 & 74.8 & 28.03 & 0.41 \\
\hline & $\begin{array}{l}\text { the strength of the back } \\
\text { muscles }\end{array}$ & 157.9 & 13.36 & 167.7 & 22.71 & 1.18 \\
\hline & $\begin{array}{l}\text { the strength of the } 2 \text { leg } \\
\text { muscles }\end{array}$ & 251.5 & 13.36 & 258.6 & 13.26 & 1.19 \\
\hline & $\begin{array}{l}\text { right fist using the } \\
\text { manometer. }\end{array}$ & 122.3 & 6.412 & 120.4 & 5.037 & 0.74 \\
\hline & $\begin{array}{l}\text { left fist using the } \\
\text { manometer. }\end{array}$ & 123.1 & 5.877 & 122.4 & 5.501 & 0.28 \\
\hline \multirow{2}{*}{$\begin{array}{c}\text { strength } \\
\text { Endurance }\end{array}$} & high rolls with dummy & 17.8 & 1.549 & 17.1 & 1.791 & 0.93 \\
\hline & $\begin{array}{l}\text { bottom rolls with } \\
\text { dummy }\end{array}$ & 42.5 & 3.1 & 40.8 & 3.552 & 1.14 \\
\hline \multirow[t]{2}{*}{ Balance } & Fixes & 21.38 & 1.161 & 21.49 & 1.194 & 0.21 \\
\hline & Kinetic & 4.5 & 0.527 & 4.6 & 0.516 & 0.43 \\
\hline \multirow{2}{*}{ Flexibility } & Horizontal & 40.6 & 15.66 & 45.8 & 7.48 & 0.95 \\
\hline & Vertical & 47.4 & 2.011 & 45.9 & 3.414 & 1.19 \\
\hline
\end{tabular}

The $\mathrm{T}$ value of the table is at the level of $(0.05)=2.101$

Table (2) shows that there are statistically unexpressive differences between the two groups (experimental/control) in the variables under consideration, indicating the equivalence of the two groups in these variables, since the value of the calculated " $\mathrm{T}$ " is less than the "T"

Tools and devices used in data collection.

Reference survey

The

researcher

conducted a survey of scientific studies and references that dealt with cross-training, functional strength, center muscles, side 
flipping up and down, and also references that dealt with weight training within the limits available to the researcher in order to identify the methods and physical content of the training programs used. And also benefit from them in how to develop the program and the formation of loads and use the results in the discussion of the results of the current study.

\section{Questionnaire} Annex (2)

The researcher designed a questionnaire form to explore the opinions of the experts Annex (1) in the field of study variables through communication and interviews to express opinion on the program variables. And exercises and determine the physical variables and determine the appropriate tests to measure them, in the period from 1/1/2018 AD to 25/ 1/ $2018 \mathrm{AD}$, and has been taken into account the addendum and deletion in accordance with the opinion of experts.

Tests used in research. Annex (4)

Power characterized by speed (Time of 3 high rolls with the stand, Time of 4 rolls of the waist from the bottom with the stand, Time of 8 lifts with a high roll of the lifting device from the bottom, Time of 8 waist rolls from the bottom with the use of the device of pull weights from the bottom)

Explosive force (Roll the waist by the fellow from the bottom, Roll the waist by the fellow from the top) in the same time of one roll of the negative fellow) using Movie Maker program to measure time.

The maximum kinetic force of (the high grip roll of the weightlifting device from the bottom. The waist grip roll of the weightlifting device from the bottom, straight abdominal muscles with torso drape, the right oblique abdominal muscles of the weights to bend the torso, the left oblique abdominal muscles of the weights to bend the torso. The back muscles with the weights material for the back)

The fixed maximum lift force of (the high roll with dynamometer, the waist roll of the dynamometer, the back muscles using the dynamometer, the 2 leg muscles using the dynamometer, the right fist 
using the manometer., the left fist using the manometer)

(The ability of the high beam to hold the force with the stand the ability of the waist beam to hold the force with the stand) when repeating the roll with the stand for one minute Balance (static- motor) by performing the skill of the bridge and get rid of the circular shape on the line of zone and stability on the front and one foot after 30 seconds rest Flexibility (horizontal vertical)

Devices and tools used in research.

Electronic weight measurement scale for the nearest $\mathrm{kg}$ - Restameter to measure lengths to the nearest centimeter- stop clock to measure time estimated in seconds and nearest 0.01 of a second- manometer to measure the strength of the gripdynamometer to measure static force. Wrestling rug- multiweight wrestling grills- a pull weights device from the bottom and consists of a cable crossover calibrated and a charger, a lower-back or lumbar extension) calibrated, crunch with Chest Pad calibrated, and a calibrated rotary torso weights device, standard weight training gym with multi-weight and length weight bars. Multi-weight dumbbells, training device with cable crossover, Movie Maker to measure time, computer, video camera.

Registration form. Annex (3)

The training program Annex (5)

The training program is prepared using the following steps:

The researcher conducted a reference survey of Arabic and foreign books within the limits of the researcher's knowledge.

A survey of research and studies related to research variables was conducted in the field of wrestling training as well as weight training, functional strength and cross training.

Interview and contact with experts in wrestling.

\section{The main objective of the program}

The aim of the program is to raise the level of force variables that affect the sideflipping exercises from up and down by training the functional strength of the center muscles in a cross-sectional manner. 
Foundations of program development

Building the program according to scientific bases.

The training program should be commensurate with the objectives set.

The suitability of the program and its contents from the training for the dental stage of the selected sample.

The flexibility and adjustability of the program.

Taking advantage of previous studies that have designed similar and related training programs.

Continuity and regularity in the practice of the training program to benefit the desired.

Observing the principles and foundations of training when developing the training program for training units such as (warm-up - the main part conclusion).

Taking into account individual differences when developing the program.

take into account the basics of weight training, including: warm up before the start of weight training and then lengthening exercises and good flexibility after the end of weight training - use the correct way to breathe Determination of the weight used by the intensity required through the test of maximum weight can be lifted once.

\section{Determinants of the training program \\ Period of implementation of the program}

The proposed training program will be implemented in the special preparation period and before the competitions. The duration of the program has been set at (12) weeks with (3) training units per week. The proposed training program will be implemented inside the hall of weightlifting.

The experimental and control groups are trained (6 units) a week in three units on the rug with the same training program. At the same time and the remaining three units, the training is within the weight training hall. However, the experimental group trains with the proposed training program for the functional force in the cross-section and the control group trains with the traditional program by weights are as follows: 
Table (3)

Distribution of weekly training for both experimental and control groups

\begin{tabular}{|c|c|c|}
\hline Day & The Experimental Group & The control Group \\
\hline Saturday & \multicolumn{2}{|c|}{ Training program on the rug from 8 to $10 \mathrm{pm}$} \\
\hline Sunday & $\begin{array}{l}\text { The proposed training program } \\
\text { for the functional strength of the } \\
\text { center muscles in the cross- } \\
\text { section of the weight-bearing } \\
\text { hall from } 6 \text { to } 8 \text { pm }\end{array}$ & $\begin{array}{l}\text { Traditional training } \\
\text { program inside the } \\
\text { weightlifting hall is } \\
\text { from } 8 \text { to } 10 \mathrm{pm}\end{array}$ \\
\hline Monday & \multicolumn{2}{|c|}{ Training program on the rug from 8 to $10 \mathrm{pm}$} \\
\hline Tuesday & $\begin{array}{l}\text { The proposed training program } \\
\text { for the functional strength of the } \\
\text { center muscles in the cross- } \\
\text { section of the weight-bearing } \\
\text { hall from } 8 \text { to } 10 \mathrm{pm}\end{array}$ & $\begin{array}{l}\text { Traditional training } \\
\text { program inside the } \\
\text { weightlifting hall is } \\
\text { from } 6 \text { to } 8 \mathrm{pm}\end{array}$ \\
\hline Wednesday & \multicolumn{2}{|c|}{ Training program on the rug from 8 to $10 \mathrm{pm}$} \\
\hline Thursday & $\begin{array}{l}\text { The proposed training program } \\
\text { for the functional strength of the } \\
\text { center muscles in the cross- } \\
\text { section of the weight-bearing } \\
\text { hall from } 6 \text { to } 8 \text { pm }\end{array}$ & $\begin{array}{l}\text { Traditional training } \\
\text { program inside the } \\
\text { weightlifting hall is } \\
\text { from } 8 \text { to } 10 \mathrm{pm}\end{array}$ \\
\hline Friday & \multicolumn{2}{|c|}{ Weekly rest } \\
\hline
\end{tabular}

The proposed training program has been divided into two phases:

The first phase and duration (4 weeks) aims to establish the stages of force and are divided into:

Development of power bearing and its duration (3 units).

Development maximum strength and its duration (3 units).

Explosive development and its duration (3 units).

Development of strength characteristic of speed and its duration (3 units).
The second stage and its duration (8 weeks) aims at developing the strengths variables by the functional strength drills of the core in the cross-style

- Number of units of the proposed training program to develop strengths variables by functional strength drills of core functions in cross- style (36 units) divided into (establishing 12 units +24 units to develop strengths variables by functional strength drills of 
core functions in cross- style according to relative importance).

- Training time (120 minutes)

- Total program time (4320 minutes) i.e. (72 hours)

- Training methods used:

(Low intensity training, high intensity training, repetitive training)

- Determination of the intensity of training loads:

The intensity of the training loads used in the program was determined with the maximum severity (95-

Table (4)

Identify duplicates according to the maximum weight that can be lifted once

\begin{tabular}{|c|c|c|c|c|}
\hline $\begin{array}{c}\text { Load } \\
\text { Degree }\end{array}$ & Intensity & Repetition & Sets & $\begin{array}{c}\text { Rest } \\
\text { between sets }\end{array}$ \\
\hline \multirow{2}{*}{ Maximum } & $100 \%$ & 1 & 1 & \multirow{2}{*}{$1.5: 3 \mathrm{~min}$} \\
\hline & $95 \%$ & 2 & $1-3$ & \\
\hline \multirow{4}{*}{$\begin{array}{c}\text { Lower than } \\
\text { Maximum }\end{array}$} & $93 \%$ & 3 & $1-3$ & \multirow{4}{*}{$3: 4 \min$} \\
\hline & $90 \%$ & 4 & $1-3$ & \\
\hline & $87 \%$ & 5 & $3-4$ & \\
\hline & $85 \%$ & 6 & $3-4$ & \\
\hline \multirow{4}{*}{ High } & $83 \%$ & 7 & $3-4$ & \multirow{4}{*}{$3: 5 \mathrm{~min}$} \\
\hline & $80 \%$ & 8 & $3-4$ & \\
\hline & $77 \%$ & 9 & $3-5$ & \\
\hline & $75 \%$ & 10 & $3-5$ & \\
\hline \multirow{2}{*}{ Moderate } & $67 \%$ & 12 & $3-5$ & \multirow{2}{*}{$1.5: 3 \mathrm{~min}$} \\
\hline & $65 \%$ & 15 & $3-5$ & \\
\hline \multirow{3}{*}{ Low } & $60 \%$ & 18 & $3-4$ & \multirow{3}{*}{$1: 4 \mathrm{~min}$} \\
\hline & $55 \%$ & 20 & $3-4$ & \\
\hline & $50 \%$ & 52 & $3-4$ & \\
\hline
\end{tabular}

(7: 121) 
Development variables and testing of muscle strength * Maximum power

Intensity 85\%: $100 \%$, Repeat from 1 to 4 times, Groups from 1 to 6, Comfort between Groups from 2 to 4 minutes

Conditions for maximum force tests (for one non-recurrent performance to be tested, to recognize maximum resistance the lab can overcome, for the performance to be similar to that for an athletic activity).

* Explosive power

Intensity 40\%: $75 \%$, Repeat from 1 to 6, Groups from 4 to 10, Comfort Between Groups from 2 to 5 minutes

Conditions for explosive strength tests (maximum muscle action for a single muscle contraction in the shortest time, performance similar to athletic activity).

* Featured strength of Speed Intensity 50\%: 80\%, Repeat from 6 to 12, Groups from 4 to 6 , Rest between Groups from 2 to 5 minutes Conditions for

Distinction Force Tests with Speed (Repeat against resistance of at least $10 \%$ of maximum weight and do not exceed body weight, Performance time up to 15 seconds, Performance as fast as possible, Performance similar to Sports Activity).

* strength Endurance

Intensity 40\%: 70\%, frequency of $20: 30$ frequency, groups from 4 to 6 , comfort among groups from 1 to 4 minutes

Conditions for strength Endurance Tested force requirements (Performance time of from 1 to 1.5 minutes, performance as quickly as possible, performance should be similar to sport activity).(51: 258-295) (20: 213-216) (37: 156, 166) (40: 48)

Arrangement of Training of muscle strength variables within the weight-training module

First the maximum strength.

Second, explosive force.

Third, Featured strength of Speed

The fourth is the bearing force (46: 92)

Training of muscle strength in the weights of the control group

- Training is done in the traditional way, namely training the muscles of the body in general so that in today 
is training a large muscle with a small muscle.

- Also training on all muscles in a circular form using all weight machines (bars from sitting position on the seat and dumbbells from the sitting position on the seat and fixed devices) with insufficient attention to the motor paths of the skills used or types of exercises.

- Or training by group performance with gradual increase to reach maximum strength.

\section{Survey studies}

The researcher selected a random sample of the research community consisting of (10) players from outside the basic research sample, and conducted the tests with the help of assistants, on 2/2/2018: 23/2/2018.

\section{Objective of this study}

- Ensure the integrity of the implementation and application of measurements and tests and the validity of devices and tools and related procedures in accordance with the conditions laid down and the extent of appropriate place.

- Determine the time required for the measurement process and the time taken by each player for each test when measuring.

- Identify the mistakes that can be made during the implementation of tests and measurements and the order of their progress and their suitability for the age range.

- Make sure that the module's time is appropriate to achieve its goal by implementing a test module and trying its contents.

- Measurement of the
maximum weight can be
lifted once for the members of the research sample for each of the exercises used in the program, on 19/2/2018: 23/2/2018. Annex (6)

- Learn how to use the User Training Card, which is distributed to each player during the training module. Annex (7)

- Explain how the exercises used in practice and how to breathe correctly while performing as well as how to read and implement training card content, and how to move between exercises.

The tests were confirmed to be suitable for the research sample as well as the tools and the place of the measurements, as well as to ensure that assistants are familiar with how the tests are conducted to avoid measurement errors.

\section{Validate the test:}

The researcher calculated the validity of the distinction between two groups, one of which is not distinguished from outside the original sample and the other (exploratory) 2: $8 / 2 / 2018$ and the number of each group (10) wrestlers. 
Table (5)

The significance of the differences between the two groups (Both distinctive or non- distinctive) in the tests under consideration $\mathbf{N} 1=\mathbf{N} 2=(10)$

\begin{tabular}{|c|c|c|c|c|c|c|c|}
\hline & & Variables & $\begin{array}{r}\text { Dist } \\
\text { grou }\end{array}$ & $\begin{array}{l}\text { ictive } \\
(\mathrm{n}=10)\end{array}$ & $\begin{array}{l}\text { In dis } \\
\text { group }\end{array}$ & $\begin{array}{l}\text { inctive } \\
(\mathbf{n}=10)\end{array}$ & $\mathbf{T}$ \\
\hline & & & Mean & St.Div & Mean & St.Div & \\
\hline & & $\begin{array}{l}\text { Time of } 3 \text { high rolls } \\
\text { with dummy }\end{array}$ & 7.048 & 0.283 & 8.619 & 0.576 & 7.73 \\
\hline & 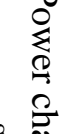 & $\begin{array}{l}\text { Time of } 4 \text { rolls of the } \\
\text { waist from the bottom } \\
\text { with dummy }\end{array}$ & 5.45 & 0.354 & 6.825 & 0.628 & 6.02 \\
\hline & 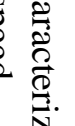 & $\begin{array}{l}\text { Time of } 8 \text { lifts with a } \\
\text { high roll of the lifting } \\
\text { device from the bottom }\end{array}$ & 12.66 & 0.154 & 13.98 & 0.534 & 7.53 \\
\hline & 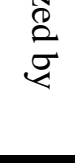 & $\begin{array}{l}\text { Time of } 8 \text { waist rolls from } \\
\text { the bottom with the use of } \\
\text { the device of pull weights } \\
\text { from the bottom }\end{array}$ & 17.62 & 0.229 & 18.54 & 0.733 & 3.81 \\
\hline Exp & sive & $\begin{array}{l}\text { Roll the waist by the } \\
\text { fellow from the bottom }\end{array}$ & 1.757 & 0.236 & 2.38 & 0.389 & 4.32 \\
\hline & & $\begin{array}{l}\text { Roll the waist by the } \\
\text { fellow from the top }\end{array}$ & 2.35 & 0.095 & 3.345 & 0.285 & 10.5 \\
\hline 3 & & $\begin{array}{l}\text { The maximum kinetic } \\
\text { force of the high grip } \\
\text { roll of the weightlifting } \\
\text { device from the bottom }\end{array}$ & 151 & 8.432 & 140.4 & 5.621 & 3.31 \\
\hline 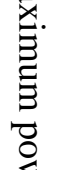 & 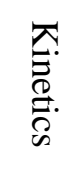 & $\begin{array}{l}\text { The maximum kinetic } \\
\text { force of the waist grip } \\
\text { roll of the weightlifting } \\
\text { device from the bottom }\end{array}$ & 114 & 7.745 & 104 & 9.66 & 2.55 \\
\hline 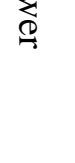 & & $\begin{array}{l}\text { The maximum kinetic } \\
\text { force of straight } \\
\text { abdominal muscles with } \\
\text { torso drape }\end{array}$ & 54.5 & 3.689 & 47 & 2.581 & 5.27 \\
\hline & & $\begin{array}{l}\text { The maximum kinetic } \\
\text { force of the right } \\
\text { oblique abdominal } \\
\text { muscles of the weights } \\
\text { to bend the torso }\end{array}$ & 43.5 & 2.415 & 40 & 3.333 & 2.69 \\
\hline
\end{tabular}


Follow Table (5)

The significance of the differences between the two groups (Both distinctive or non- distinctive) in the tests under consideration $\mathbf{N} 1=\mathbf{N} 2=(10)$

\begin{tabular}{|c|c|c|c|c|c|c|}
\hline & \multirow[t]{2}{*}{ Variables } & \multicolumn{2}{|c|}{$\begin{array}{c}\text { Distinctive } \\
\text { group }(n=10)\end{array}$} & \multicolumn{2}{|c|}{$\begin{array}{l}\text { In distinctive } \\
\text { group }(n=10)\end{array}$} & \multirow[t]{2}{*}{$\mathbf{T}$} \\
\hline & & Mean & St.Div & Mean & St.Div & \\
\hline & $\begin{array}{l}\text { The maximum kinetic } \\
\text { force of the left oblique } \\
\text { abdominal muscles of the } \\
\text { weights to bend the torso }\end{array}$ & 38.5 & 2.415 & 35.5 & 2.838 & 2.55 \\
\hline & $\begin{array}{l}\text { The maximum kinetic force } \\
\text { of the back muscles with the } \\
\text { weights material for the back }\end{array}$ & 66 & 3.162 & 58 & 2.581 & 6.19 \\
\hline & $\begin{array}{l}\text { The fixed maximum lift } \\
\text { force of the high roll }\end{array}$ & 143.5 & 5.296 & 135.3 & 4.377 & 3.68 \\
\hline 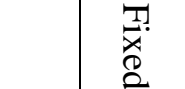 & $\begin{array}{l}\text { The maximum fixed } \\
\text { strength of the waist roll }\end{array}$ & 69.9 & 20.59 & 48.5 & 4.836 & 3.2 \\
\hline 忘 & $\begin{array}{l}\text { the strength of the } \\
\text { back muscles }\end{array}$ & 154.8 & 19.99 & 136.3 & 13.83 & 2.41 \\
\hline 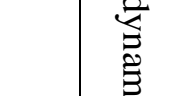 & $\begin{array}{c}\text { the strength of the } 2 \\
\text { leg muscles }\end{array}$ & 258.2 & 14.11 & 211.6 & 41.34 & 3.37 \\
\hline$\underset{0}{0}$ & $\begin{array}{l}\text { right fist using the } \\
\text { manometer. }\end{array}$ & 119.1 & 5.877 & 112.2 & 6.876 & 2.41 \\
\hline & $\begin{array}{l}\text { left fist using the } \\
\text { manometer. }\end{array}$ & 123.1 & 5.342 & 113.4 & 5.253 & 4.09 \\
\hline strength & high rolls with dummy & 17.9 & 1.595 & 15.2 & 1.135 & 4.36 \\
\hline Endurance & bottom rolls with dummy & 40.8 & 3.583 & 36.3 & 2.496 & 3.26 \\
\hline Balance & Fixes & 21.83 & 1.239 & 16.92 & 1.435 & 8.19 \\
\hline & Kinetic & 4.6 & 0.516 & 2.8 & 0.422 & 8.54 \\
\hline Fleyibili & Horizontal & 43.7 & 6.254 & 51.6 & 2.836 & 3.64 \\
\hline Flexibillty & Vertical & 44.8 & 2.485 & 41.8 & 1.813 & 3.08 \\
\hline
\end{tabular}

The value of "T" of the table (2.101) at a significant level (0.05)

Table

statistically

(5)

significant

differences in favor of the characteristic group indicating the validity of the tests.

\section{Stability tests}

The

researcher calculated the stability of the tests using the re-tests on the survey sample of (10) wrestlers 
on $15: 17 / 2 / 2018$ after a period between the two applications.

of time interval of a week

\section{Table (6)}

Arithmetical mean, standard deviation and correlation coefficient Between the first application and the second application of the physical tests in question for the exploratory sample $N=(10)$

\begin{tabular}{|c|c|c|c|c|c|c|c|}
\hline & \multicolumn{2}{|c|}{ Variables } & \multicolumn{2}{|c|}{$\begin{array}{c}1^{\text {st }} \\
\text { application }\end{array}$} & \multicolumn{2}{|c|}{$\begin{array}{c}2^{\text {nd }} \\
\text { application }\end{array}$} & \multirow[t]{2}{*}{$\mathbf{R}$} \\
\hline & & & Mean & St.Div & Mean & St.Div & \\
\hline & & $\begin{array}{c}\text { Time of } 3 \text { high rolls } \\
\text { with dummy }\end{array}$ & 7.048 & 0.283 & 6.97 & 0.323 & 0.97 \\
\hline & $\sum_{0}^{\Sigma}$ & $\begin{array}{l}\text { Time of } 4 \text { rolls of the waist from } \\
\text { the bottom with dummy }\end{array}$ & 5.45 & 0.354 & 5.4 & 0.371 & 0.99 \\
\hline & 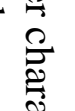 & $\begin{array}{l}\text { Time of } 8 \text { lifts with a } \\
\text { high roll of the lifting } \\
\text { device from the bottom }\end{array}$ & 12.66 & 0.154 & 12.61 & 0.152 & 0.98 \\
\hline & 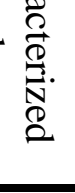 & $\begin{array}{l}\text { Time of } 8 \text { waist rolls } \\
\text { from the bottom with } \\
\text { the use of the device } \\
\text { of pull weights from } \\
\text { the bottom }\end{array}$ & 17.62 & 0.229 & 17.55 & 0.263 & 0.74 \\
\hline Exp & sive & $\begin{array}{l}\text { Roll the waist by the } \\
\text { fellow from the bottom }\end{array}$ & 1.757 & 0.236 & 1.68 & 0.274 & 0.78 \\
\hline & & $\begin{array}{l}\text { Roll the waist by the } \\
\text { fellow from the top }\end{array}$ & 2.35 & 0.095 & 2.28 & 0.122 & 0.89 \\
\hline & & $\begin{array}{l}\text { The maximum kinetic } \\
\text { force of the high grip } \\
\text { roll of the weightlifting } \\
\text { device from the bottom }\end{array}$ & 151 & 8.432 & 152.5 & 8.579 & 0.96 \\
\hline 3 & & $\begin{array}{l}\text { The maximum kinetic } \\
\text { force of the waist grip } \\
\text { roll of the weightlifting } \\
\text { device from the bottom }\end{array}$ & 114 & 7.745 & 116.5 & 7.09 & 0.94 \\
\hline 肴. & 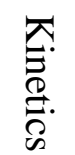 & $\begin{array}{l}\text { The maximum kinetic } \\
\text { force of straight } \\
\text { abdominal muscles } \\
\text { with torso drape }\end{array}$ & 54.5 & 3.689 & 56 & 3.944 & 0.8 \\
\hline $\begin{array}{l}0 \\
\varrho \\
9\end{array}$ & & $\begin{array}{l}\text { The maximum kinetic force } \\
\text { of the right oblique } \\
\text { abdominal muscles of the } \\
\text { weights to bend the torso }\end{array}$ & 43.5 & 2.415 & 44.5 & 2.838 & 0.69 \\
\hline & & $\begin{array}{l}\text { The maximum kinetic } \\
\text { force of the left oblique } \\
\text { abdominal muscles of } \\
\text { the weights to bend the } \\
\text { torso }\end{array}$ & 38.5 & 2.415 & 39.5 & 2.838 & 0.69 \\
\hline
\end{tabular}


Follow Table (6)

Arithmetical mean, standard deviation and correlation coefficient

Between the first application and the second application of the physical tests in question for the exploratory sample $N=(10)$

\begin{tabular}{|c|c|c|c|c|c|c|}
\hline \multirow{2}{*}{\multicolumn{2}{|c|}{ Variables }} & \multicolumn{2}{|c|}{$\begin{array}{c}1^{\text {st }} \\
\text { application }\end{array}$} & \multicolumn{2}{|c|}{$\begin{array}{c}2^{\text {nd }} \\
\text { application }\end{array}$} & \multirow[t]{2}{*}{$\mathbf{R}$} \\
\hline & & \multirow{2}{*}{$\begin{array}{c}\text { Mean } \\
66\end{array}$} & \multirow{2}{*}{$\begin{array}{l}\text { St.Div } \\
3.162\end{array}$} & \multirow{2}{*}{$\begin{array}{c}\text { Mean } \\
67.5\end{array}$} & \multirow{2}{*}{$\begin{array}{l}\text { St.Div } \\
3.535\end{array}$} & \\
\hline \multirow{7}{*}{ 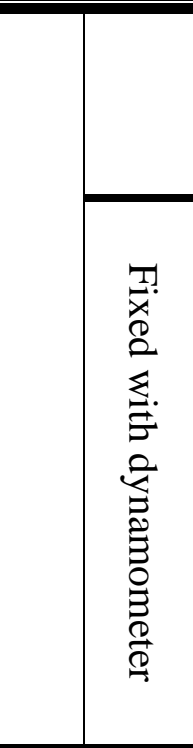 } & $\begin{array}{l}\text { The maximum kinetic } \\
\text { force of the back } \\
\text { muscles with the } \\
\text { weights material for } \\
\text { the back }\end{array}$ & & & & & 0.75 \\
\hline & $\begin{array}{l}\text { The fixed maximum } \\
\text { lift force of the high } \\
\text { roll }\end{array}$ & 143.5 & 5.296 & 145.6 & 5.168 & 0.89 \\
\hline & $\begin{array}{l}\text { The maximum fixed } \\
\text { strength of the waist } \\
\text { roll }\end{array}$ & 69.9 & 20.59 & 70.7 & 20.61 & 0.99 \\
\hline & $\begin{array}{l}\text { the strength of the } \\
\text { back muscles }\end{array}$ & 154.8 & 19.99 & 155.5 & 20.34 & 0.99 \\
\hline & $\begin{array}{l}\text { the strength of the } 2 \\
\text { leg muscles }\end{array}$ & 258.2 & 14.11 & 259.1 & 13.71 & 0.99 \\
\hline & $\begin{array}{l}\text { right fist using the } \\
\text { manometer. }\end{array}$ & 119.1 & 5.877 & 120.1 & 6.008 & 0.97 \\
\hline & $\begin{array}{l}\text { left fist using the } \\
\text { manometer. }\end{array}$ & 123.1 & 5.342 & 124.3 & 6.219 & 0.96 \\
\hline \multirow{2}{*}{$\begin{array}{l}\text { strength } \\
\text { Endurance }\end{array}$} & $\begin{array}{c}\text { high rolls with } \\
\text { dummy }\end{array}$ & 17.9 & 1.595 & 18.1 & 1.37 & 0.97 \\
\hline & $\begin{array}{c}\text { bottom rolls with } \\
\text { dummy }\end{array}$ & 40.8 & 3.583 & 41.1 & 3.212 & 0.98 \\
\hline \multirow[t]{2}{*}{ Balance } & Fixes & 21.83 & 1.239 & 21.75 & 1.258 & 0.99 \\
\hline & Kinetic & 4.6 & 0.516 & 4.7 & 0.483 & 0.8 \\
\hline \multirow{2}{*}{ Flexibility } & Horizontal & 43.7 & 6.254 & 43.3 & 5.793 & 0.99 \\
\hline & Vertical & 44.8 & 2.485 & 45.1 & 2.469 & 0.96 \\
\hline
\end{tabular}

The value of "R" of the table (0.632) at a significant level (0.05)

Table (6) shows that the calculated " $R$ " value is greater than the "R" value of the table, indicating the stability of the tests in question.
3. Measurement of the maximum weight can be lifted once for the members of the research sample for each of the exercises used in the 
program, on 19/2/2018:

23/2/2018.

\section{- Pre-measurements:}

The Pre measurements were conducted for the members of the research sample on $25 / 2 / 2018$ to $3 / 3 / 2018$

- Implementation of the program:

The proposed program was implemented from 4/3/2018 to 24/5/2018

- Post-measurements:

Measurements were carried out on $25 / 5 / 2018$ to View and discuss the results First, view the results

Table (7)

The significance of the differences between the measurement (pre/post) of the experimental group in the physical variables in question $\mathrm{N}=(\mathbf{1 0})$

\begin{tabular}{|c|c|c|c|c|c|c|}
\hline \multirow{2}{*}{\multicolumn{2}{|c|}{ Variables }} & \multicolumn{2}{|c|}{ Premeasure } & \multicolumn{2}{|c|}{ Post-measure } & \multirow{3}{*}{$\frac{\mathbf{T}}{24.1^{*}}$} \\
\hline & & \multirow{2}{*}{$\begin{array}{l}\text { Mean } \\
7.015\end{array}$} & \multirow{2}{*}{$\begin{array}{l}\text { St.Div } \\
0.653\end{array}$} & \multirow{2}{*}{$\begin{array}{l}\text { Mean } \\
5.811\end{array}$} & \multirow{2}{*}{$\frac{\text { St.Div }}{0.578}$} & \\
\hline$\tau$ & $\begin{array}{l}\text { Time of } 3 \text { high } \\
\text { rolls with dummy }\end{array}$ & & & & & \\
\hline $\begin{array}{l}\sum \\
\varrho \\
\varrho \\
\varrho\end{array}$ & $\begin{array}{l}\text { Time of } 4 \text { rolls of } \\
\text { the waist from the } \\
\text { bottom with dummy }\end{array}$ & 5.334 & 0.321 & 4.238 & 0.327 & $24.5^{*}$ \\
\hline 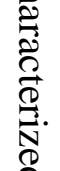 & $\begin{array}{l}\text { Time of } 8 \text { lifts } \\
\text { with a high roll of } \\
\text { the lifting device } \\
\text { from the bottom }\end{array}$ & 12.75 & 0.15 & 11.21 & 0.113 & $27.4^{*}$ \\
\hline $\begin{array}{l}2 \\
\sigma \\
0 \\
0 \\
0 \\
\mathbb{8} \\
\infty\end{array}$ & $\begin{array}{l}\text { Time of } 8 \text { waist rolls } \\
\text { from the bottom } \\
\text { with the use of the } \\
\text { device of pull } \\
\text { weights from the } \\
\text { bottom }\end{array}$ & 17.71 & 0.217 & 16.1 & 0.754 & $23.9 *$ \\
\hline
\end{tabular}

Assiut Journal For Sport Science Arts
$31 / 5 / 2018$ with the same conditions and specifications of pre-measurement and in the same place.

\section{Statistical Processes:}

In this study, the researcher used the following statistical processes:

- Arithmetic mean- standard deviation- mean- torsion coefficient

- Coefficient of correlationcoefficient $\mathrm{Eta}^{2}$ - test the significance of differences $(T)$ - the percentage of improvement 
Follow Table (7)

The significance of the differences between the measurement (pre/post) of the experimental group in the physical variables in question $\mathrm{N}=(\mathbf{1 0})$

\begin{tabular}{|c|c|c|c|c|c|c|c|}
\hline & \multirow{2}{*}{\multicolumn{2}{|c|}{ Variables }} & \multicolumn{2}{|c|}{ Premeasure } & \multicolumn{2}{|c|}{ Post-measure } & \multirow{2}{*}{$\mathbf{T}$} \\
\hline & & & \multirow{2}{*}{$\begin{array}{l}\text { Mean } \\
1.664\end{array}$} & \multirow{2}{*}{$\begin{array}{c}\text { St.Div } \\
0.33\end{array}$} & \multirow{2}{*}{$\begin{array}{l}\text { Mean } \\
1.164\end{array}$} & \multirow{2}{*}{$\begin{array}{l}\text { St.Div } \\
0.171\end{array}$} & \\
\hline \multirow{2}{*}{\multicolumn{2}{|c|}{$\begin{array}{l}\text { Explosive } \\
\text { force }\end{array}$}} & $\begin{array}{l}\text { Roll the waist by } \\
\text { the fellow from } \\
\text { the bottom }\end{array}$ & & & & & $7.2^{*}$ \\
\hline & & $\begin{array}{l}\text { Roll the waist by the } \\
\text { fellow from the top }\end{array}$ & 2.338 & 0.217 & 1.941 & 0.196 & $13.8 *$ \\
\hline \multirow{6}{*}{ 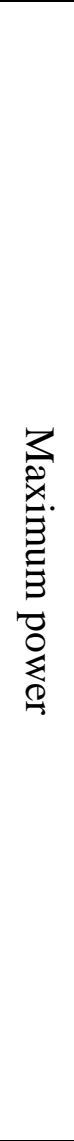 } & \multirow{6}{*}{ 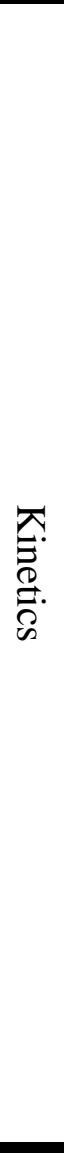 } & $\begin{array}{l}\text { The maximum } \\
\text { kinetic force of the } \\
\text { high grip roll of the } \\
\text { weightlifting device } \\
\text { from the bottom }\end{array}$ & 150.5 & 8.316 & 168 & 8.563 & $15.7 *$ \\
\hline & & $\begin{array}{l}\text { The maximum } \\
\text { kinetic force of the } \\
\text { waist grip roll of the } \\
\text { weightlifting device } \\
\text { from the bottom }\end{array}$ & 115.5 & 7.619 & 133 & 8.232 & $13 *$ \\
\hline & & $\begin{array}{l}\text { The maximum kinetic } \\
\text { force of straight } \\
\text { abdominal muscles } \\
\text { with torso drape }\end{array}$ & 53 & 2.581 & 65.5 & 4.377 & $11.2 *$ \\
\hline & & $\begin{array}{l}\text { The maximum } \\
\text { kinetic force of the } \\
\text { right oblique } \\
\text { abdominal muscles } \\
\text { of the weights to } \\
\text { bend the torso }\end{array}$ & 41.5 & 2.415 & 53.5 & 4.116 & $14.7 *$ \\
\hline & & $\begin{array}{l}\text { The maximum } \\
\text { kinetic force of the } \\
\text { left oblique } \\
\text { abdominal muscles } \\
\text { of the weights to } \\
\text { bend the torso }\end{array}$ & 41.5 & 3.374 & 56.5 & 5.797 & $11.6^{*}$ \\
\hline & & $\begin{array}{l}\text { The maximum } \\
\text { kinetic force of the } \\
\text { back muscles with } \\
\text { the weights material } \\
\text { for the back }\end{array}$ & 66 & 3.944 & 83.5 & 7.472 & $11.4^{*}$ \\
\hline
\end{tabular}


Follow Table (7)

The significance of the differences between the measurement (pre/post) of the experimental group in the physical variables in question $\mathrm{N}=(\mathbf{1 0})$

\begin{tabular}{|c|c|c|c|c|c|c|}
\hline \multirow{2}{*}{\multicolumn{2}{|c|}{ Variables }} & \multicolumn{2}{|c|}{ Premeasure } & \multicolumn{2}{|c|}{ Post-measure } & \multirow{2}{*}{$\mathbf{T}$} \\
\hline & & Mean & \multirow{2}{*}{$\begin{array}{l}\text { St.Div } \\
6.582\end{array}$} & \multirow{2}{*}{$\begin{array}{l}\text { Mean } \\
157\end{array}$} & \multirow{2}{*}{$\begin{array}{r}\text { St.Div } \\
8.232\end{array}$} & \\
\hline 导 & $\begin{array}{c}\text { The fixed } \\
\text { maximum lift } \\
\text { force of the high } \\
\text { roll }\end{array}$ & 139 & & & & $11.8 *$ \\
\hline & $\begin{array}{l}\text { The maximum } \\
\text { fixed strength of } \\
\text { the waist roll }\end{array}$ & 70.3 & 21.03 & 100 & 21.03 & $19.7 *$ \\
\hline & $\begin{array}{l}\text { the strength of the } \\
\text { back muscles }\end{array}$ & 157.9 & 13.36 & 184.1 & 12.39 & $37.6^{*}$ \\
\hline & $\begin{array}{l}\text { the strength of the } \\
2 \text { leg muscles }\end{array}$ & 251.5 & 13.36 & 283.5 & 13.13 & $14.7 *$ \\
\hline & $\begin{array}{l}\text { right fist using the } \\
\text { manometer. }\end{array}$ & 122.3 & 6.412 & 134.8 & 4.237 & $15^{*}$ \\
\hline & $\begin{array}{l}\text { left fist using the } \\
\text { manometer. }\end{array}$ & 123.1 & 5.877 & 134.6 & 5.081 & $25.4 *$ \\
\hline \multirow{2}{*}{$\begin{array}{l}\text { strength } \\
\text { Endurance }\end{array}$} & $\begin{array}{l}\text { high rolls with } \\
\text { dummy }\end{array}$ & 17.8 & 1.549 & 24.4 & 1.837 & $21.6^{*}$ \\
\hline & $\begin{array}{l}\text { bottom rolls with } \\
\text { dummy }\end{array}$ & 42.5 & 3.1 & 48.6 & 3.169 & $26.1 *$ \\
\hline \multirow[t]{2}{*}{ Balance } & Fixes & 21.38 & 1.161 & 34.4 & 1.809 & $18.6^{*}$ \\
\hline & Kinetic & 4.5 & 0.527 & 9 & 0.817 & $13.2 *$ \\
\hline \multirow{2}{*}{ Flexibility } & Horizontal & 40.6 & 15.66 & 31.4 & 13.82 & $15.1^{*}$ \\
\hline & Vertical & 47.4 & 2.011 & 51.8 & 1.686 & $14.4^{*}$ \\
\hline
\end{tabular}

Table (7) shows that there are statistical function differences between the two pre and post-measurements of the experimental group for the benefit of post-measurements in the physical variables in question, as the calculated value of test(s) is higher than the sum of the tabular value(s) of all variables. 
Table (8)

Indication of the differences between the measurement (pre/post) of the control group in the physical variables in question $\mathrm{N}=(10)$

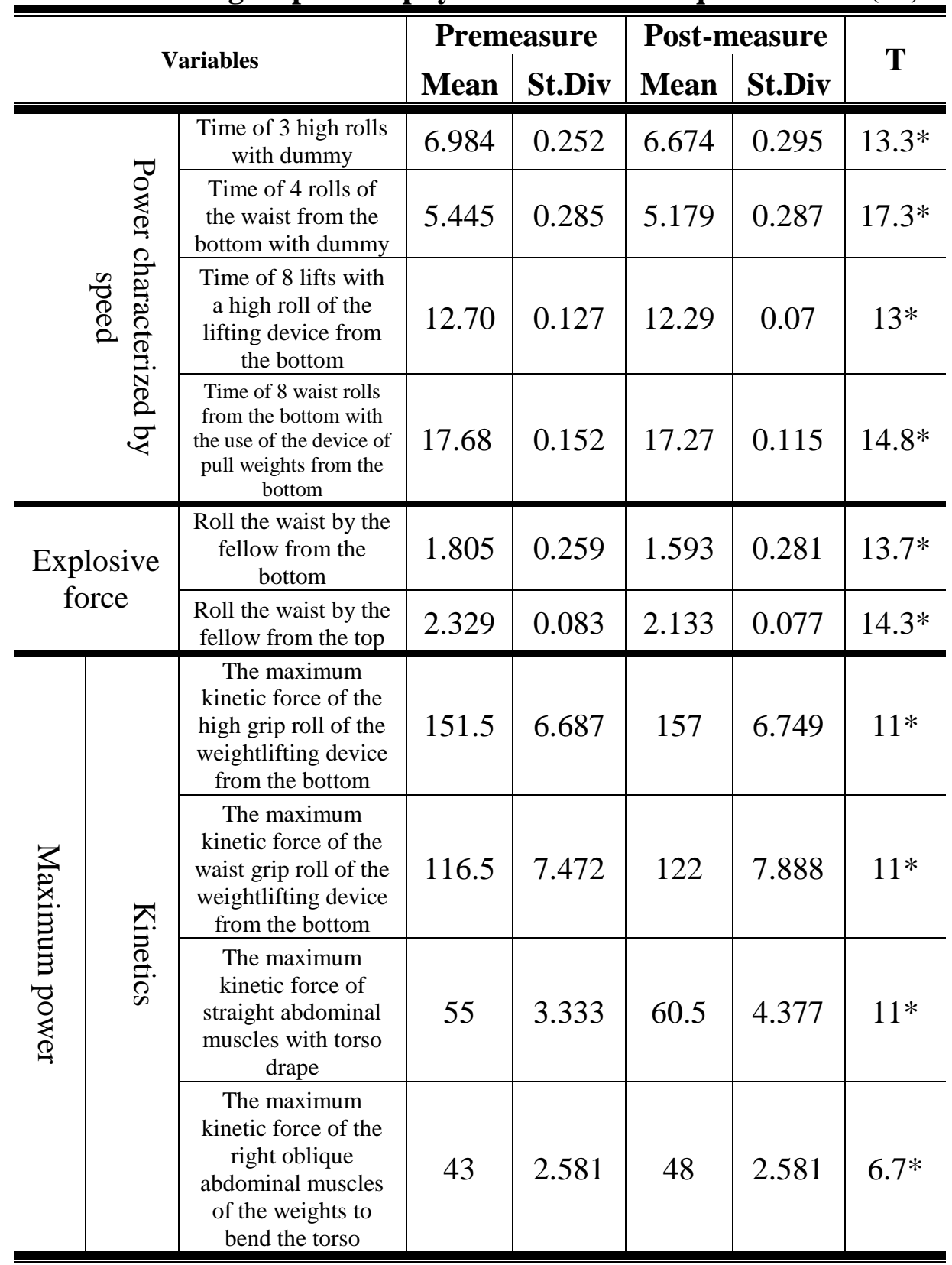


Follow Table (8)

Indication of the differences between the measurement (pre/post) of the control group in the physical variables in question $N=(10)$

\begin{tabular}{|c|c|c|c|c|c|c|}
\hline \multirow{2}{*}{\multicolumn{2}{|c|}{ Variables }} & \multicolumn{2}{|c|}{ Premeasure } & \multicolumn{2}{|c|}{ Post-measure } & \multirow{2}{*}{$\mathbf{T}$} \\
\hline & & Mean & St.Div & Mean & St.Div & \\
\hline \multirow{8}{*}{ 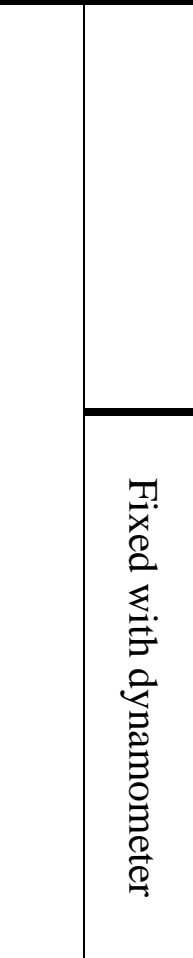 } & $\begin{array}{l}\text { The maximum } \\
\text { kinetic force of the } \\
\text { left oblique } \\
\text { abdominal muscles } \\
\text { of the weights to } \\
\text { bend the torso }\end{array}$ & 41 & 3.162 & 45.5 & 2.838 & $9 *$ \\
\hline & $\begin{array}{l}\text { The maximum } \\
\text { kinetic force of the } \\
\text { back muscles with } \\
\text { the weights material } \\
\text { for the back }\end{array}$ & 66 & 3.162 & 71.5 & 3.374 & $11^{*}$ \\
\hline & $\begin{array}{l}\text { The fixed maximum } \\
\text { lift force of the high } \\
\text { roll }\end{array}$ & 143 & 4.216 & 148.9 & 4.254 & $13.6^{*}$ \\
\hline & $\begin{array}{l}\text { The maximum fixed } \\
\text { strength of the waist } \\
\text { roll }\end{array}$ & 74.8 & 28.03 & 76.3 & 28.14 & $9 *$ \\
\hline & $\begin{array}{l}\text { the strength of the } \\
\text { back muscles }\end{array}$ & 167.7 & 22.71 & 169.4 & 22.37 & $3 *$ \\
\hline & $\begin{array}{c}\text { the strength of the } 2 \\
\text { leg muscles }\end{array}$ & 258.6 & 13.26 & 264.7 & 13.33 & $10.8^{*}$ \\
\hline & $\begin{array}{l}\text { right fist using the } \\
\text { manometer. }\end{array}$ & 120.4 & 5.037 & 126.8 & 5.996 & $2.3^{*}$ \\
\hline & $\begin{array}{l}\text { left fist using the } \\
\text { manometer. }\end{array}$ & 122.4 & 5.501 & 126.4 & 5.777 & $15.5^{*}$ \\
\hline \multirow{2}{*}{$\begin{array}{l}\text { strength } \\
\text { Endurance }\end{array}$} & $\begin{array}{c}\text { high rolls with } \\
\text { dummy }\end{array}$ & 17.1 & 1.791 & 20.2 & 3.852 & $2.8^{*}$ \\
\hline & $\begin{array}{c}\text { bottom rolls with } \\
\text { dummy }\end{array}$ & 40.8 & 3.552 & 43.6 & 3.627 & $11.2^{*}$ \\
\hline \multirow[t]{2}{*}{ Balance } & Fixes & 21.49 & 1.194 & 21.51 & 1.181 & 1.5 \\
\hline & Kinetic & 4.6 & 0.516 & 4.8 & 0.362 & 1.5 \\
\hline \multirow{2}{*}{ Flexibility } & Horizontal & 45.8 & 7.48 & 44.7 & 7.543 & $11^{*}$ \\
\hline & Vertical & 45.9 & 3.414 & 47.8 & 3.359 & $10.6^{*}$ \\
\hline
\end{tabular}

Value of (T) in table (1.833) at a significant level (0.05)

Table (8) shows that significant differences between there are statistically the pre and post-measurements 
of the control group in favor of the post-measurement in the physical variables in question.
The value of calculated $(\mathrm{t})$ in test is higher than the tabular value.

\section{Table (9)}

The significance of differences between the two postmeasurements of the experimental and control groups in the physical variables in question $\mathrm{N}=\mathrm{N} 2=(10)$

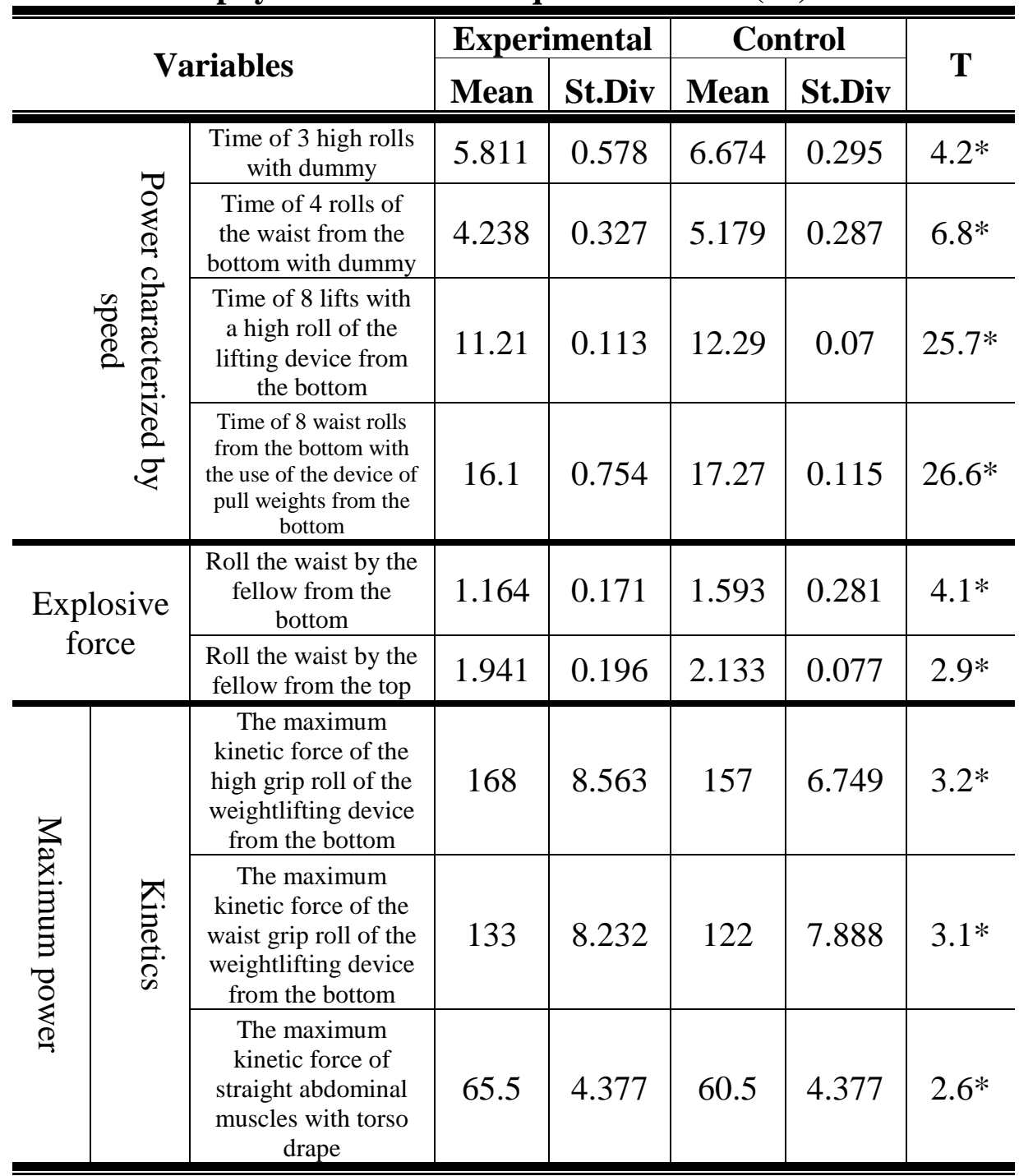


Follow Table (9)

The significance of differences between the two postmeasurements of the experimental and control groups in the physical variables in question $\mathrm{N}=\mathbf{N} 2=(\mathbf{1 0})$

\begin{tabular}{|c|c|c|c|c|c|c|}
\hline \multirow{2}{*}{\multicolumn{2}{|c|}{ Variables }} & \multicolumn{2}{|c|}{ Experimental } & \multicolumn{2}{|c|}{ Control } & \multirow{2}{*}{$\mathbf{T}$} \\
\hline & & \multirow[t]{2}{*}{ Mean } & \multirow{2}{*}{$\begin{array}{l}\text { St.Div } \\
4.116\end{array}$} & \multirow{2}{*}{$\begin{array}{c}\text { Mean } \\
48\end{array}$} & \multirow{2}{*}{$\begin{array}{l}\text { St.Div } \\
2.581\end{array}$} & \\
\hline & $\begin{array}{l}\text { The maximum } \\
\text { kinetic force of the } \\
\text { right oblique } \\
\text { abdominal muscles } \\
\text { of the weights to } \\
\text { bend the torso }\end{array}$ & & & & & $3.6^{*}$ \\
\hline & $\begin{array}{l}\text { The maximum kinetic } \\
\text { force of the left } \\
\text { oblique abdominal } \\
\text { muscles of the weights } \\
\text { to bend the torso }\end{array}$ & 56.5 & 5.797 & 45.5 & 2.838 & $5.4^{*}$ \\
\hline & $\begin{array}{l}\text { The maximum } \\
\text { kinetic force of the } \\
\text { back muscles with } \\
\text { the weights material } \\
\text { for the back }\end{array}$ & 83.5 & 7.472 & 71.5 & 3.374 & $4.6^{*}$ \\
\hline \multirow{6}{*}{ 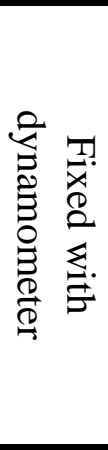 } & $\begin{array}{l}\text { The fixed maximum lift } \\
\text { force of the high roll }\end{array}$ & 157 & 8.232 & 148.9 & 4.254 & $2.8 *$ \\
\hline & $\begin{array}{l}\text { The maximum fixed } \\
\text { strength of the waist roll }\end{array}$ & 100 & 21.03 & 76.3 & 28.14 & $2.1^{*}$ \\
\hline & $\begin{array}{l}\text { the strength of the } \\
\text { back muscles }\end{array}$ & 184.1 & 12.39 & 169.4 & 22.37 & $1.8 *$ \\
\hline & $\begin{array}{c}\text { the strength of the } 2 \\
\text { leg muscles }\end{array}$ & 283.5 & 13.13 & 264.7 & 13.33 & $3.1 *$ \\
\hline & $\begin{array}{l}\text { right fist using the } \\
\text { manometer. }\end{array}$ & 134.8 & 4.237 & 126.8 & 5.996 & $3.4^{*}$ \\
\hline & $\begin{array}{l}\text { left fist using the } \\
\text { manometer. }\end{array}$ & 134.6 & 5.081 & 126.4 & 5.777 & $3.4^{*}$ \\
\hline \multirow{2}{*}{$\begin{array}{l}\text { strength } \\
\text { Endurance }\end{array}$} & $\begin{array}{l}\text { high rolls with } \\
\text { dummy }\end{array}$ & 24.4 & 1.837 & 20.2 & 3.852 & $3.1 *$ \\
\hline & $\begin{array}{l}\text { bottom rolls with } \\
\text { dummy }\end{array}$ & 48.6 & 3.169 & 43.6 & 3.627 & $3.3^{*}$ \\
\hline \multirow[t]{2}{*}{ Balance } & Fixes & 34.4 & 1.809 & 21.51 & 1.181 & $18.8^{*}$ \\
\hline & Kinetic & 9 & 0.817 & 4.8 & 0.362 & $12.9 *$ \\
\hline \multirow{2}{*}{ Flexibility } & Horizontal & 31.4 & 13.82 & 44.7 & 7.543 & $2.7 *$ \\
\hline & Vertical & 51.8 & 1.686 & 47.8 & 3.359 & $3.4^{*}$ \\
\hline
\end{tabular}

The value of $(\mathrm{T})$ in table (1.734) at a significant level (0.05)

Assiut Journal For Sport Science Arts 
Table (9) shows that there are statistically significant differences between the two post-measurements of the experimental and control groups in favor of the physical variables in question $N=(10)$

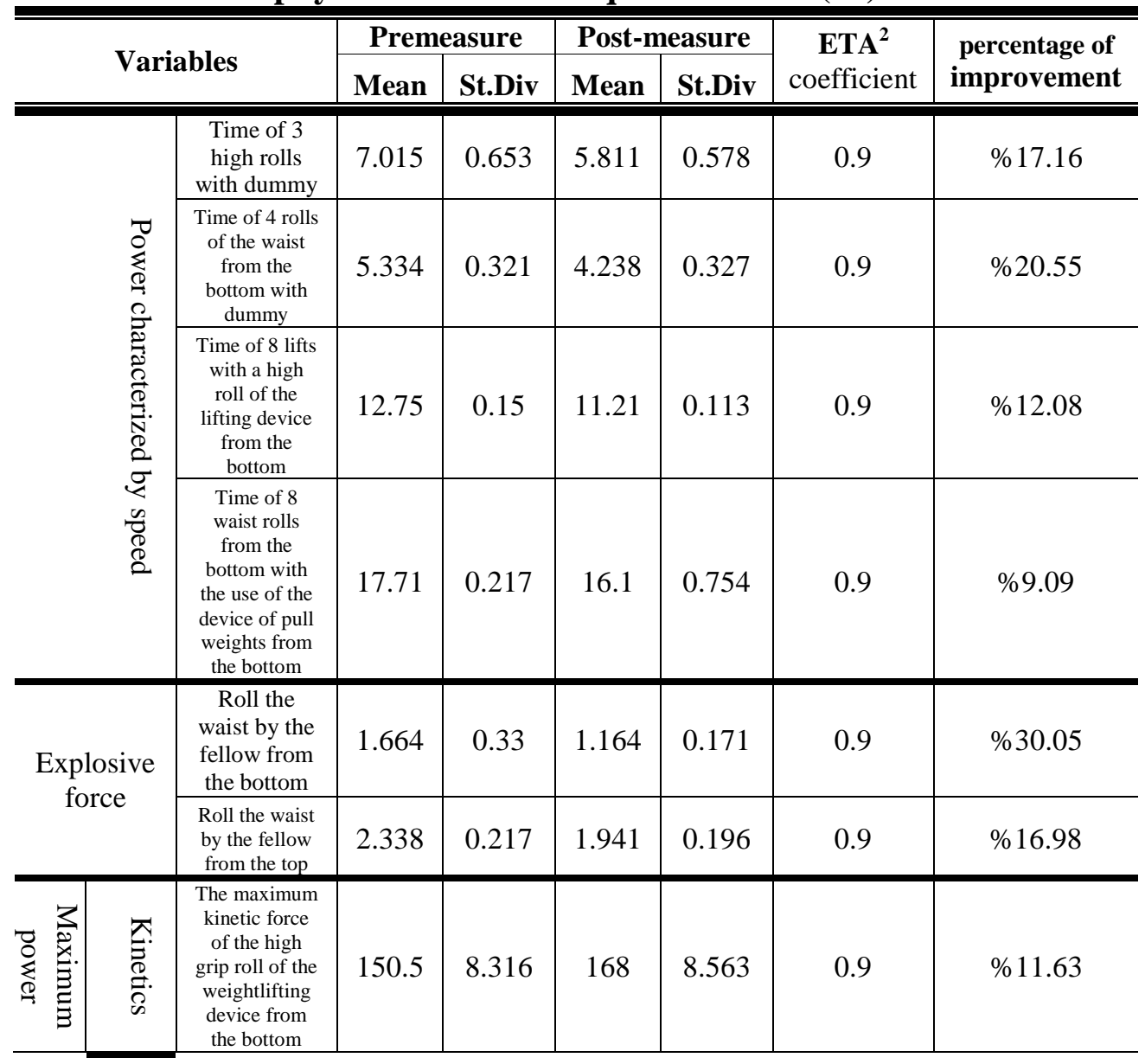

experimental group in the physical variables in question. The value of the test $(\mathrm{t})$ calculated is higher than the tabular value.

\section{Table (10) \\ The value of the ETA 2 program and the improvement between the measurement (pre/post) of the experimental group in the}


Follow Table (10)

The value of the ETA 2 program and the improvement between the measurement (pre/post) of the experimental group in the physical variables in question $\mathrm{N}=(\mathbf{1 0})$

\begin{tabular}{|c|c|c|c|c|c|c|c|}
\hline \multirow{2}{*}{\multicolumn{2}{|c|}{ Variables }} & \multicolumn{2}{|c|}{ Premeasure } & \multicolumn{2}{|c|}{ Post-measure } & \multirow{2}{*}{$\begin{array}{c}\text { ETA }^{2} \\
\text { coefficient }\end{array}$} & \multirow{2}{*}{$\begin{array}{l}\text { percentage of } \\
\text { improvement }\end{array}$} \\
\hline & & Mean & St.Div & Mean & St.Div & & \\
\hline & $\begin{array}{l}\text { The maximum } \\
\text { kinetic force of } \\
\text { the waist grip } \\
\text { roll of the } \\
\text { weightlifting } \\
\text { device from } \\
\text { the bottom }\end{array}$ & 115.5 & 7.619 & 133 & 8.232 & 0.9 & $\% 15.15$ \\
\hline & $\begin{array}{l}\text { The maximum } \\
\text { kinetic force of } \\
\text { straight } \\
\text { abdominal } \\
\text { muscles with } \\
\text { torso drape } \\
\end{array}$ & 53 & 2.581 & 65.5 & 4.377 & 0.9 & $\% 23.58$ \\
\hline & $\begin{array}{l}\text { The maximum } \\
\text { kinetic force of } \\
\text { the right } \\
\text { oblique } \\
\text { abdominal } \\
\text { muscles of the } \\
\text { weights to } \\
\text { bend the torso }\end{array}$ & 41.5 & 2.415 & 53.5 & 4.116 & 0.9 & $\% 28.92$ \\
\hline & $\begin{array}{l}\text { The maximum } \\
\text { kinetic force of } \\
\text { the left oblique } \\
\text { abdominal } \\
\text { muscles of the } \\
\text { weights to } \\
\text { bend the torso }\end{array}$ & 41.5 & 3.374 & 56.5 & 5.797 & 0.9 & $\% 36.14$ \\
\hline & $\begin{array}{l}\text { The maximum } \\
\text { kinetic force of } \\
\text { the back } \\
\text { muscles with } \\
\text { the weights } \\
\text { material for } \\
\text { the back }\end{array}$ & 66 & 3.944 & 83.5 & 7.472 & 0.9 & $\% 26.52$ \\
\hline 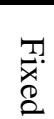 & $\begin{array}{l}\text { The fixed } \\
\text { maximum lift } \\
\text { force of the } \\
\text { high roll }\end{array}$ & 139 & 6.582 & 157 & 8.232 & 0.9 & $\% 12.95$ \\
\hline 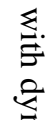 & $\begin{array}{c}\text { The maximum } \\
\text { fixed strength } \\
\text { of the waist } \\
\text { roll }\end{array}$ & 70.3 & 21.03 & 100 & 21.03 & 0.9 & $\% 42.25$ \\
\hline 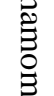 & $\begin{array}{c}\text { the strength of } \\
\text { the back } \\
\text { muscles }\end{array}$ & 157.9 & 13.36 & 184.1 & 12.39 & 0.9 & $\% 16.59$ \\
\hline$\stackrel{\overparen{\oplus}}{\oplus}$ & $\begin{array}{l}\text { the strength of } \\
\text { the } 2 \text { leg } \\
\text { muscles }\end{array}$ & 251.5 & 13.36 & 283.5 & 13.13 & 0.9 & $\% 12.73$ \\
\hline
\end{tabular}

Assiut Journal For Sport Science Arts 
Follow Table (10)

The value of the ETA 2 program and the improvement between the measurement (pre/post) of the experimental group in the physical variables in question $\mathrm{N}=(\mathbf{1 0})$

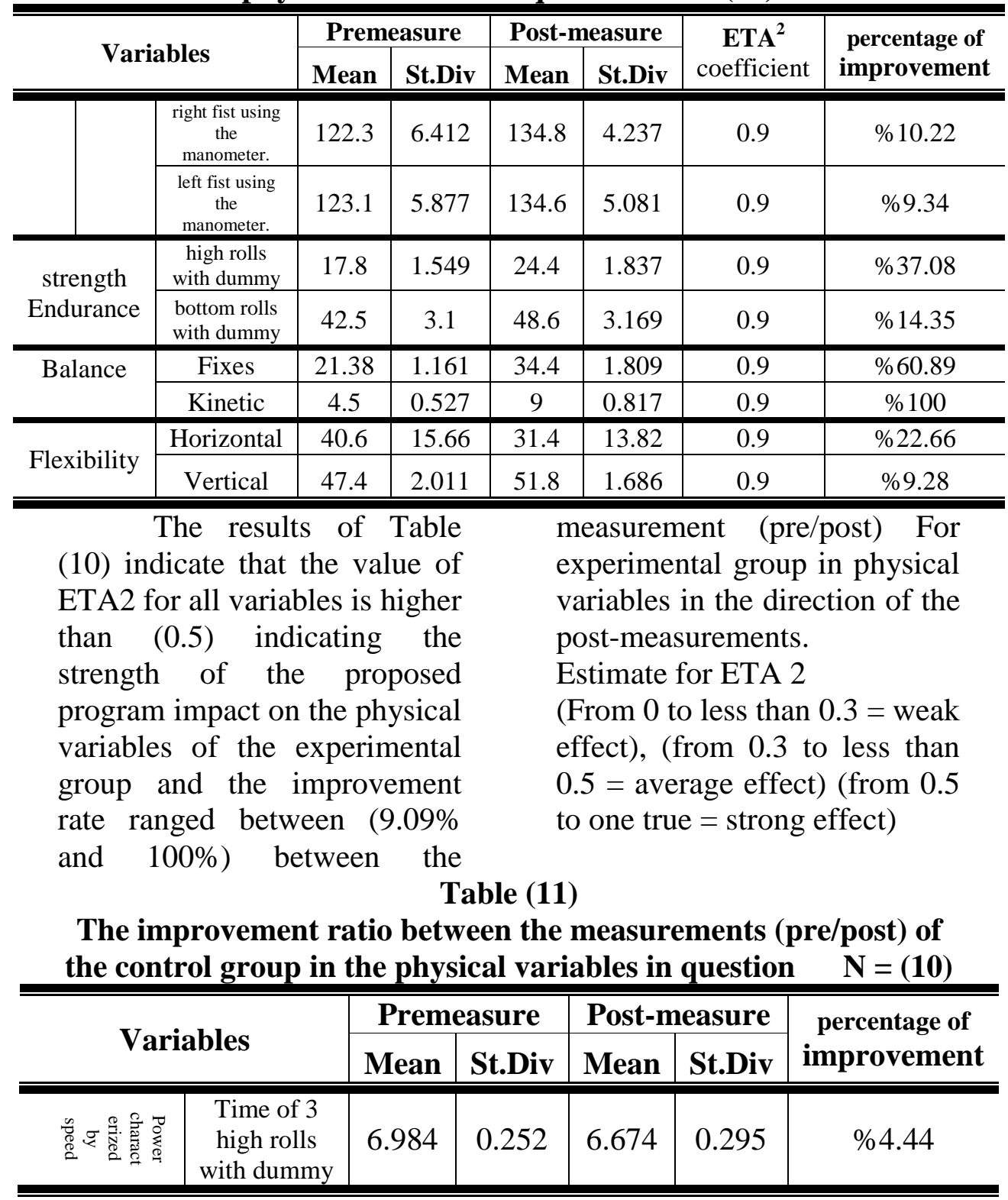


Table (11)

The improvement ratio between the measurements (pre/post) of the control group in the physical variables in question $\mathbf{N}=(10)$

\begin{tabular}{|c|c|c|c|c|c|c|c|}
\hline & \multirow{2}{*}{\multicolumn{2}{|c|}{ Variables }} & \multicolumn{2}{|c|}{ Premeasure } & \multicolumn{2}{|c|}{ Post-measure } & \multirow{2}{*}{$\begin{array}{l}\text { percentage of } \\
\text { improvement }\end{array}$} \\
\hline & & & Mean & St.Div & Mean & St.Div & \\
\hline & & $\begin{array}{l}\text { Time of } 4 \text { rolls } \\
\text { of the waist } \\
\text { from the } \\
\text { bottom with } \\
\text { dummy }\end{array}$ & 5.445 & 0.285 & 5.179 & 0.287 & $\% 5.89$ \\
\hline & & $\begin{array}{c}\text { Time of } 8 \text { lifts } \\
\text { with a high roll } \\
\text { of the lifting } \\
\text { device from the } \\
\text { bottom }\end{array}$ & 12.70 & 0.127 & 12.29 & 0.07 & $\% 3.23$ \\
\hline & & $\begin{array}{l}\text { Time of } 8 \text { waist } \\
\text { rolls from the } \\
\text { bottom with the } \\
\text { use of the } \\
\text { device of pull } \\
\text { weights from } \\
\text { the bottom }\end{array}$ & 17.68 & 0.152 & 17.27 & 0.115 & $\% 2.32$ \\
\hline \multirow{2}{*}{\multicolumn{2}{|c|}{$\begin{array}{l}\text { Explosive } \\
\text { force }\end{array}$}} & $\begin{array}{l}\text { Roll the waist by } \\
\text { the fellow from } \\
\text { the bottom }\end{array}$ & 1.805 & 0.259 & 1.593 & 0.281 & $\% 11.75$ \\
\hline & & $\begin{array}{l}\text { Roll the waist by } \\
\text { the fellow from } \\
\text { the top }\end{array}$ & 2.329 & 0.083 & 2.133 & 0.077 & $\% 8.42$ \\
\hline \multirow{3}{*}{ 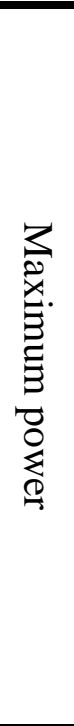 } & \multirow{3}{*}{ 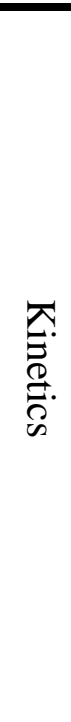 } & $\begin{array}{l}\text { The maximum } \\
\text { kinetic force of } \\
\text { the high grip } \\
\text { roll of the } \\
\text { weightlifting } \\
\text { device from the } \\
\text { bottom }\end{array}$ & 151.5 & 6.687 & 157 & 6.749 & $\% 3.63$ \\
\hline & & $\begin{array}{l}\text { The maximum } \\
\text { kinetic force of } \\
\text { the waist grip } \\
\text { roll of the } \\
\text { weightlifting } \\
\text { device from the } \\
\text { bottom }\end{array}$ & 116.5 & 7.472 & 122 & 7.888 & $\% 4.72$ \\
\hline & & $\begin{array}{c}\text { The } \\
\text { maximum } \\
\text { kinetic force } \\
\text { of straight } \\
\text { abdominal } \\
\text { muscles with } \\
\text { torso drape }\end{array}$ & 55 & 3.333 & 60.5 & 4.377 & $\% 10$ \\
\hline
\end{tabular}


Follow Table (11)

The improvement ratio between the measurements (pre/post) of the control group in the physical variables in question $\mathbf{N}=(10)$

\begin{tabular}{|c|c|c|c|c|c|c|}
\hline \multirow{2}{*}{\multicolumn{2}{|c|}{ Variables }} & \multicolumn{2}{|c|}{ Premeasure } & \multicolumn{2}{|c|}{ Post-measure } & \multirow{2}{*}{$\begin{array}{l}\text { percentage of } \\
\text { improvement }\end{array}$} \\
\hline & & \multirow{2}{*}{$\begin{array}{c}\text { Mean } \\
43\end{array}$} & \multirow{2}{*}{$\begin{array}{l}\text { St.Div } \\
2.581\end{array}$} & \multirow{2}{*}{$\begin{array}{c}\text { Mean } \\
48\end{array}$} & \multirow{2}{*}{$\begin{array}{l}\text { St.Div } \\
2.581\end{array}$} & \\
\hline & $\begin{array}{l}\text { The maximum } \\
\text { kinetic force of } \\
\text { the right oblique } \\
\text { abdominal } \\
\text { muscles of the } \\
\text { weights of bend } \\
\text { the torso }\end{array}$ & & & & & $\% 11.63$ \\
\hline & $\begin{array}{l}\text { The maximum } \\
\text { kinetic force of } \\
\text { the left oblique } \\
\text { abdominal } \\
\text { muscles of the } \\
\text { weights to bend } \\
\text { the torso }\end{array}$ & 41 & 3.162 & 45.5 & 2.838 & $\% 10.98$ \\
\hline & $\begin{array}{c}\text { The maximum } \\
\text { kinetic force of } \\
\text { the back muscles } \\
\text { with the weights } \\
\text { material for the } \\
\text { back }\end{array}$ & 66 & 3.162 & 71.5 & 3.374 & $\% 8.33$ \\
\hline \multirow{6}{*}{ 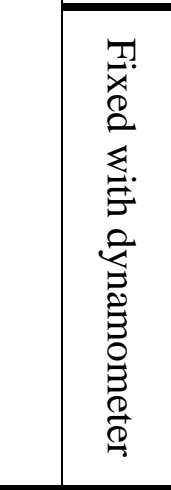 } & $\begin{array}{c}\text { The fixed } \\
\text { maximum lift } \\
\text { force of the high } \\
\text { roll }\end{array}$ & 143 & 4.216 & 148.9 & 4.254 & $\% 4.13$ \\
\hline & $\begin{array}{l}\text { The maximum } \\
\text { fixed strength of } \\
\text { the waist roll }\end{array}$ & 74.8 & 28.03 & 76.3 & 28.14 & $\% 2.01$ \\
\hline & $\begin{array}{l}\text { the strength of the } \\
\text { back muscles }\end{array}$ & 167.7 & 22.71 & 169.4 & 22.37 & $\% 1.01$ \\
\hline & $\begin{array}{l}\text { the strength of the } \\
2 \text { leg muscles }\end{array}$ & 258.6 & 13.26 & 264.7 & 13.33 & $\% 6.23$ \\
\hline & $\begin{array}{l}\text { right fist using } \\
\text { the manometer. }\end{array}$ & 120.4 & 5.037 & 126.8 & 5.996 & $\% 5.32$ \\
\hline & $\begin{array}{l}\text { left fist using } \\
\text { the manometer. }\end{array}$ & 122.4 & 5.501 & 126.4 & 5.777 & $\% 3.27$ \\
\hline \multirow{2}{*}{$\begin{array}{l}\text { strength } \\
\text { Endurance }\end{array}$} & $\begin{array}{c}\text { high rolls } \\
\text { with dummy }\end{array}$ & 17.1 & 1.791 & 20.2 & 3.852 & $\% 18.13$ \\
\hline & $\begin{array}{l}\text { bottom rolls } \\
\text { with dummy }\end{array}$ & 40.8 & 3.552 & 43.6 & 3.627 & $\% 6.86$ \\
\hline \multirow[t]{2}{*}{ Balance } & Fixes & 21.49 & 1.194 & 21.51 & 1.181 & $\% 0.09$ \\
\hline & Kinetic & 4.6 & 0.516 & 4.8 & 0.362 & $\% 4.35$ \\
\hline \multirow{2}{*}{ Flexibility } & Horizontal & 45.8 & 7.48 & 44.7 & 7.543 & $\% 2.4$ \\
\hline & Vertical & 45.9 & 3.414 & 47.8 & 3.359 & $\% 4.14$ \\
\hline
\end{tabular}


The results of Table (11) indicate that the value of the improvement rate ranged between $(0.09 \%$ and $18.13 \%)$ between the measurements (pre/post) of the control group in the physical variables in the direction of the postmeasurements.

\section{Second, discuss the results}

In the light of the previous presentation of the researcher's findings and within the framework of the objectives and research hypotheses and guided by the results of the previous studies and the scientific references, the researcher begins discussing these results as follows:

Table (7) shows that there are statistically significant differences between the measurement (tribal / remote) of the experimental group in the tests under study, for the tests of strength characteristic of the speed of 3 screws high $(24,056)$, The characteristic strength of the speed of four screws is the center of the bottom of the body (24.477), The characteristic strength of the speed of eight lifts with the high grip of the lifting device from the bottom (27.415), The characteristic strength of the speed of four screws of the bottom is 24.477, The characteristic strength of the speed of eight lifts with the high grip of the lifting device from the bottom (27.415), The characteristic strength of the speed of eight screws with the middle of the center from the bottom of the weight of the pull device (23.883), The explosive force of the center of screws from the bottom (7.151), The explosive power of the middle screws from above (13.807); The maximum kinetic strength of the high wire rope with the lifting weight device from below $(15,652)$, The maximum kinetic strength of the center of the screws with the pull device from below (13.024); Maximum kinetic strength of the abdominal muscles with the second weight of the trunk (11.18), The Maximum kinetic strength of the right oblique abdominal muscles in the trunk (14.697), The Maximum kinetic force of the left oblique abdominal muscles with the trunk (11.619), The maximum kinetic strength of the back muscles with the back weight 
device (11.389), The maximum fixed lift force of the high screws by the dynamometer (11.784), The maximum fixed strength of the center of the screws by the dynamometer (19.722), The maximum fixed strength of the back muscles using the dynamometer (37.643), The maximum fixed strength of leg muscles using the dynamometer (14.708), The maximum fixed force of the right fist using the manometer (15), The maximum fixed strength of the left fist using the manometer (25.365), The bearing force to hold the upper high screws (21.604), The bearing force to hold the center of the screws (26.143), The horizontal balance (18.618), the motor balance (13.175), the horizontal elasticity (15.057), the vertical elasticity (14.402), Which is higher than the value of tabular $\mathrm{T}$ (1.833) at the degree of freedom (9), indicating that the proposed training program to develop the strength variables by training the functional strength set by the researcher for the muscles of the Center in a cross-section style, which took into account the working muscles and kinetic paths of skill performance Which affected the physical variables in question

Mohammed

Ashmawi (2003) (34) Alaa Qinnawi (1996) (5) say that In order for the wrestler to effectively implement the skills in the matches, this requires special preparation, including the physical side, linked to the skillful side.

The important exercises that help to develop the muscle strength of the muscles of the center, which is the muscles of the abdomen and back and these are the most important features of functional strength training and they focus on the center muscle group. (8:3)

\section{Zaki}

Mohamed

Mohamed Hassan (2004), Mohamed Gaber Barka, Ihab Fawzi El-Badioui (2004) indicate that muscle strength is the basis or the main basis for cross-training activities for most sports activities, especially activities that depend on muscle strength of all kinds and speed and explosive movements such as wrestling. (61: 17) (35:8)

This is confirmed by Mus'ad Ali Mahmoud and others (1995) that weight training is an objective means 
of developing the different types of muscular strength that the wrestler desperately needs and plays a fundamental and essential role in increasing the efficiency of the skillful performance of the wrestler. (40: 77)

As shown in Table (10), the value of the ETA 2 coefficient was the impact of the program (0.9) and was greater than (0.5) This indicates that the proposed training program for the development of the strength variables by the functional strength exercises set by the researcher for the center muscles in a cross-section style and develop the strength variables within the unit starting with the exercises of maximum strength, After completion, we move to the explosive force and then to the strength characteristic of the speed and finally the force bearing, taking into account the load variables of each element of force, which control the movement of the working muscles and the kinetic path of the skills using the functional strength exercises of the center muscles using the crosssectional style. Which had a great impact and that the training of the functional strength developed by the researcher was effective in the development of physical capabilities under consideration The researcher was interested in setting the scientific basis for the development of exercises similar to the work of muscle with the requirements of the performance of the skill and in the same muscular and dynamic path, which had a great impact on those variables, this is consistent with Salah Asran (1996)(50) that muscle strength is one of the most important requirements of wrestling sport due to the nature of performance and the multiplicity of ingredients needed by the wrestler during the implementation of offensive movements and defensive counter-attack, Mohammed Hassan Allawi and Abu al-Ala'a Abd alFattah (2000) assert that the development of mobility skills is closely linked to the development of the necessary physical fitness components, since the player cannot master the dynamic skills of the type of specialized sports activity if 
he lacks the physical attributes necessary for this type of activity. (36:80)

\section{Zaki}

Mohammad

Hassan (2004), Mohamed Jabir Barka, Ihab Fawzi AlBadiwi (2004) emphasize that cross-training is a tool or a means of training that helps the player to reach the highest level of competition in his or her specialized sport (61: 14)(35: 5)

\section{Amal Mohammed}

Mousa (2005) points out that the functional strength training is an important exercise that helps to develop the muscle strength of the core, which is represented in the abdomen and back muscles, and this is one of the most important features of the functional strength training, which is the focus on the center muscle group. (8:3)

\section{Wesam Samy (2016)} agrees that functional strength training helps to develop the muscular strength of the center area because it contains exercises that help strengthen the abdominal and back muscles. The strong center muscles move the movement from the lower end to the upper limb and prevent the leakage of force. It also works to strike a balance between the two sides and the imbalance in the center area will affect the skill and physical performance. [58]

The results of Table (10) show that the improvement rate between the (pre/post) measurements of the experimental group in the physical variables in question was in favor of the postmeasurement The improvement rate ranged between (9.09\% and 100\%) indicating that the proposed training program to develop the power variables by training the functional strength developed by the researcher for the muscles of the center in a cross-way has led to the development of the physical variables under consideration and that the use of difference in weight training from the usual has added the principle of diversity and change as a principle of the principles and fundamentals of sports training will remove the monotony and boredom, and increases the rush of players to exert effort in the performance of their training units and this leads to the maximum benefit of training, as Mousa Fahmy, 
Adel Ali (1994) that the purpose of the exercises is to prepare specific muscle groups to fit with the type of activity In other words, they develop the muscles working in the skill with attention to the technical aspects side by side and often these exercises are difficult and complex. (39:93)

These results are consistent with the study of Essam Mohammed Saqr (2020)(21), Tamer Imad al-Din Saeed (2017)(53), Wessam Mohamed (2016)(58), Tamer Emad Eddin Saeed (2016)(54), Ebraheem Faraj (2015)(15), Ayman Muslim Sulaiman (2015)(9), Walid Saleh Abdul Gawad (2014)(56), Moataz Mohammed Najib (2014)(33), Belal Morsi Witwit (2016)(13) Ehab Fawzy Al-Badawi (2004)(16), Belal Morsi Witwit (2016)(12) Belal Morsi Witwit (2014)(11), Nabil Al-Shorbagi (2008)(42), Mohamed Ismail Al-Jammal (2007)(30), Mohamed El-Sayed Ashmawy (2003)(34), Ahmed Shaarawi Mohamed Ahmed (2002)(3).

Table (8) shows that there is a statistically significant difference between the (pre/post) measurements of the control group in the following tests where the calculated value (T) for the strength tests characteristic of the speed of 3 screws high (13.259), the characteristic strength of the speed of the four screws from the bottom is 17.315 , the characteristic strength of the speed of eight lifts with the high grip of the lifting device from the bottom (13.038), the characteristic strength of the speed of eight lifts with the high grip of the pull device from the bottom (14.807), the explosive force of the center screws from bottom (13.697), the explosive force of the center screws from the top (14.329), maximum kinetic strength with high lift grip with lifting device from bottom (11), the maximum kinetic strength for holding the center screws with a pull-down weight device (11), the maximum kinetic strength of the abdominal muscles with the second weight of the trunk (11), the Maximum kinetic strength of the right abdominal muscles in the weight device (6.708), the Maximum kinetic strength of the left slanted abdominal muscles in the weight device (9), the Maximum kinetic strength of 
the back muscles in the weight device (11), the fixed maximum strength of lifting for the high screws with dynamometer (13.615), the maximum fixed strength of the screws center of the dynamometer (9), the maximum fixed strength of the back muscles using the dynamometer (3.042), the maximum fixed strength of the muscles of the legs using the dynamometer (10.765), the maximum fixed strength of the right fist using the manometer (2.324), the maximum fixed strength of the left fist using the manometer (15.492), the bearing force to hold the upper screws is high (2.793), the bearing force to hold the center of the screws (11.225), horizontal elasticity (11), vertical Flexibility (10.585), which are greater than the value of the "T" table, which was (1.833), (9) indicating that the traditional training program had an effect on these physical variables, while there were statistically significant differences in the following tests. The value of (T) was calculated for the fixed balance tests (1.5), the motor equilibrium (1.5) Less than the value of the "T" tabular which was (1.833) at the degree of freedom (9)

The researcher believes that the reason for the existence of differences in those variables is due to the neglect of weight training the researcher believes that the reason for the existence of nonsignificant differences in these variables is due to the importance of weight training in a similar manner in terms of standing and moving and not to use the appropriate training methods, which suit the system with the requirements of the performance of skill and the use of training in a random and non-directed and lack of training skills that achieve points and win fastest and not to use the training of functional strength in training, where training on the muscles of the center, which is one of the most important requirements of the skills in question.

These results are consistent with Michael Boyle (2004). Functional strength training programs must contain a combination of strength training and balancing exercises that perform simultaneously with 
acceleration, stabilization and deceleration, with the aim of improving kinetic ability and central force, whose performance requires maximum integration Strength of muscles with maximum speed of performance to achieve a high degree of ability to perform. (32: 264)

The results of Table (11) indicate the improvement rate between the (pre/post) measurements of the control group in the physical variables in question for the benefit of the post measurement. The improvement rate ranged between $(0.09 \%$ and $18.13 \%)$

The researcher attributed these differences and this improvement and this progress to the fact that the traditional training program has led to improvement in the variables under consideration of the control group for the regularity of players and their commitment to training and repeat the performance of training, which in turn improved the variables under consideration and the impact of training Adel Abd al-Basir (1999) states that adjustment in training cannot continue or develop only through continual continuous training (2: 72) and

James, P,M.(1996), indicating that regular training helps internal organs adjust to any new work, which increases the player's ability to function (28: 85)

Table (9) shows that there are statistically significant differences between the two groups (experimental / control) in the dimensional measurement in the physical abilities under consideration in favor of the experimental group where the value of $(t)$ calculated greater than the value of $(t)$ in the table at a significant level (0.05) It was (1.734) at the degree of freedom (18) Where the value of $\mathrm{T}$ calculated for the strength tests of the speed of 3 screws high (4.203), the characteristic strength of the speed of four speed of the bottom of the person (6.829), the characteristic strength of the speed of eight lifts by the high grip of the lifting device from the bottom (25.703) ), the characteristic strength of the speed of eight lifts with the high grip of the pull device from the bottom (26.649), the explosive force of the center 
screws from bottom (4.111), the explosive force of the center screws from the top (2.869), maximum kinetic strength with high lift grip with lifting device from bottom (3.19), the maximum kinetic strength for holding the center screws with a pull-down weight device (3.051), the maximum kinetic strength of the abdominal muscles with the second weight of the trunk (2.554), the Maximum kinetic strength of the right abdominal muscles in the weight device (3.579), the Maximum kinetic strength of the left slanted abdominal muscles in the weight device (5.389), the Maximum kinetic strength of the back muscles in the weight device (4.628), the fixed maximum strength of lifting for the high screws with dynamometer (2.764), the maximum fixed strength of the screws center of the dynamometer (2.133), the maximum fixed strength of the back muscles using the dynamometer (1.818), the maximum fixed strength of the muscles of the legs using the dynamometer (3.177), the maximum fixed strength of the right fist using the manometer
(3.445), the maximum fixed strength of the left fist using the manometer (3.37), the bearing force to hold the upper screws is high (3.111), the bearing force to hold the center of the screws (3.283), the horizontal balance $(18,863)$, the kinetic equilibrium (12.86), the horizontal elasticity (2.672), the vertical elasticity (3.365).

This is largely due to the effectiveness of the proposed training program for the development of force variables (maximum strength, explosive force, characteristic strength of the speed, bearing force) through the training of the functional strength set by the researcher to the muscles of the center in a cross-sectional style these results also indirectly confirm the validity of the training loads for each component of the strength within the training program used according to the method of muscle work in addition to the safety of the selection of the training of the functional force used and attention to the health and speed of performance where

Mohammed Hassan Alawi and Abu Al-ola Abdul Fattah 
(2000) confirm that the development and mastering of the kinetic skills of the type of sport activity is closely related to the development of the necessary physical abilities associated with those skills (36: 80)

\section{Tiana Weiss (2010)} points out that functional strength training is one of the most recently used methods in the development of muscle strength and that it can contribute as a way to improve technical performance that is similar to the shape and nature of performance with a focus on the full kinetic range of motion. (55)

These results are supported by the improvement rate where the results of Table (10) and (11) indicate the difference between the rate of improvement in the level between the proposed program and the traditional program.

The researcher believes that these differences and improvement rates in the experimental group is due to the proposed training program, which consists of training the functional strength of the muscles of the center in the direction of muscle work using a cross-sectional style, which was applied to the experimental group in the physical variables in question, which contains special training to develop Physical activity in which the muscle work is similar with the performance requirements of the skill and in the same kinetic path and depends on the technique of the side-end skill of the bottom and top

The researcher believes that these differences and improvement rates in the experimental group is due to the proposed training program, which consists of training the functional strength of the muscles of the center in the direction of muscle work using the cross-force development method, which was applied to the experimental group in the physical variables in question, which contains special training for capacity development In which the muscle work is similar to the working muscles and the performance requirements of the skill and in the same motor path and depends on the technique of the skills of lateral turning Below and above using different positions and holdings, these 
results agree with Ali Saeed Rayhan (1994)(6) that weight training is an objective means of developing the different types of muscle power that the wrestler needs so strongly and plays a key role in raising the efficiency of the wrestler's performance overall, and also citing German and Hanley that wrestlers need high levels of muscle power so that they can perform skills properly and efficiently. Essam Abd Elkhalek (1992) asserts that mastering a professional performance depends on the extent to which the requirements for such performance are developed from special physical capabilities and the level of professional performance is often measured by the individual's acquisition of these special physical qualities. (19:171).

\section{"Dave Schmitz"}

(2003) suggests that functional strength exercises have the characteristics and features most importantly of center muscles group that helps connect the lower end to the upper end of the core including six-pack, Spine muscles and lateral muscles, as well as preventing leakage of strength and multilevel which means performing of sports movements in more than one direction and not limiting exercise to one direction only. And multiple knuckles means that training should focus on the use of more than one knuckle instead of one, and the control of counter-balancing multidirectional movements requires balance. This is where not only requires strong muscles to the center but sufficient skill and performance compatibility, use of all ends with alternative method.

\section{Integrated}

Movement aims to increase body sensitivity, integrity and qualitative activity. This requires understanding of nature and requirements of the sports activity performed and throughout understanding the performance requirements we can identify the workouts and parameters to meet those needs, and the specific speed of performed activity. (14:3-5)

These findings are consistent with the study of Gehan Al-Sawi (2012) (24), Rami Salamah (2011)(47), Masaad Hedia (2010)(41), Marius And Others (2009)(31), 
Reda Mohammed Ibrahim (2009) (48), Alaa Mohamed Kenawy (2007) (5), Gardg, Gillk, A., Degerfeldtl (2000) (23), Yasumura And Others (2000) (60), Osama Hossny Elshorbgy (2001) (45), Nabeel Hossny Elshorbgy (2000) (43), Hamdy Abd Elrahman (1999) (25), Novikov,A (1999) (44), Sabry Ali Kotb (1997) (49), Salah Mohamed Asran (1996) (50), Ali Saied Rayhan (1994) (6).

This is consistent with the principle of privacy in training as well as taking into account the individual differences of each player where Abdulaziz Al-Namer, Nariman Al-Khatib (2005) state that performance is better improved if the training is specific to the type of activity practiced, includes the most important muscles involved in this activity and is done by the same way they are used in competition. (1:188).

From the above, the proposed training program for the experimental group, which includes the functional strength exercises for the muscles in the direction of the work of the development of the force compounds, is similar to the muscular work with the skilldriving track in question to develop muscle power compounds using the cross training technique, which has had a positive effect on the development of muscle power variables and thus achieve research offers.

\section{Conclusions:}

In the light of the objectives and nature of this study and within the sample of research and methodology used, the data collected by the researcher and the results of the statistical analysis led the researcher to the following conclusions:

1- The proposed training program using weight training using cross training technique has a positive effect on developing the maximum strength of lateral turning skills from the bottom and top of the experimental group.

2- The proposed training program using weight training using cross training technique has a positive effect on developing the explosive strength of the lateral turning skills from below and above in the experimental group.

3- The proposed training program using weight training 
using cross training technique has a positive effect on the development of the speed characteristic of the lateral turning skills from below and from above in the experimental group.

4- The proposed training program using functional weight training using cross training technique has a positive impact on developing the special strength of lateral turning skills from the bottom and top of the experimental group.

5- The proposed training program using functional weight training using cross training technique is better than the traditional program in developing the special strength variables of the lateral turning skills from the bottom and top of the experimental group.

\section{Recommendations:}

To the extent that the study has included procedures and results, the researcher recommends the following:

1- To take care of the trainings directed toward the motor tracks of the skills in question and the different skills of wrestling.

2- To take care of the training of functional weight training during the programs of wrestlers' preparing to raise the levels of power according to the scientific principles and to increase the ability to fight efficiently during matches.

3- To take care to strengthen the stem muscles as they transfer movements from the lower end to the upper end and also prevent the leakage of force, and work on striking a balance between the two sides. The imbalance in the center area will affect the physical and professional performance.

4- Interference with training programs using the cross training technique in case of failure and fluctuation in the level.

5- Take care of the trainers' field through training courses and familiarize the trainers with modern training methods.

6- The need to design similar programs for different ages.

7. The need to design similar programs using functionalpower exercises to develop the strength of the performance of different technical skills in changing conflict situations.

\section{References:}

1-Abdelazeez

Elnemr,

Nareman Elkhateeb: (2005)

Muscular strength Design 
programs of the Force and planning the training season, Professors of the sportive book, Giza.

2- Adel Abd Elbaseer: (1999) Sports training and integration between theory and application, Book Center for Publication, Cairo.

3- Ahmed Sharawy Mohamed Ahmed: (2002) The impact of the weightlifting training program on the effectiveness of the performance of the collection of back-throwing movements and some physiological variables of young wrestlers, the Master's thesis, Mansoura University.

4- Alaa Mohamed Kenawy: (1996) The effect of some elements of fitness on the performance of the back kicks movement in wrestling, Ph.D. thesis, Faculty of Sports Education, Zagazig University.

5- Alaa Mohamed Kenawy: (2007) The effectiveness of functional strength training on some physical variables and the level of performance of the skills of the opposite hold for wrestling juniors, Journal of Research in Sports Education, College of Physical Education for Boys, Zagazig University.

\section{6- Ali Elsaeed Rayhan:} (1994) Impact of Weights Program on the Effectiveness of skillful performance for wrestlers, Scientific Conference, College of Physical Education for Boys, Helwan University.

7- Ali Fahmy Elbeek And Others.: (2009) Recent Trends in Sports Training "Theories and Applications" Part III, Vol. 1, Knowledge Establishment, Alexandria.

8- Amal Mohamed Mossa: (2005) The effectiveness of integrative functional training on some specific physical variables and the level of skill performance of the balances and turns in rhythmic exercises, Journal of Research in Sports Education for Girls, Zagazig University, No. 5.

\section{9- Ayman Moslem Soliman:} (2015) A training program using functional power training and its effect on some physical variables and the level of performance of the skill of the greatest artistic hooks of wrestling players, the scientific journal of physical education and sports, Alexandria University.

10- Bastawesy Ahmed: (1999) Foundations and theories of 
sports training, Arab Thought House, Cairo.

\section{1- Belal Morsi Witwit:} (2014) A qualitative training program using composed technique and its effect on the strength of the performance of the skill of mediocre most effective from putting conflict from the bottom in free wrestling, The Journal of Comprehensive Education Research, Faculty of Sports Education, Girls of Zagazig University.

\section{2- Belal Morsy Witwit:} (2016): "The effectiveness of the use of certain Olympic bar lifting exercises in the development of under-lifting skill performance Power for wrestlers', International Journal of Sport Science \& Arts (IJSSA), Egypt.

\section{3- Belal Morsy Witwit:} (2016): 'Training strategy for the transition period using cross method to maintain physical level and bodyweight of a junior wrestler', International Journal of Sport Science \& Arts (IJSSA), Egypt.

14- Dave, S.: (2003): Functional Training Pyramids ,New Truer High School
,Kinetic Wellness Department, USA

\section{5- Ebraheem Mahmoud} Merza Farag: (2015) Impact of the performance-level functional strength exercises for young masters, unpublished master's thesis, Faculty of Physical Education, Mansoura University.

\section{6- Ehab Fawzy Elbedwey :} (2004) Impact of a program using casual training on some physical, physiological and effective performance of the skill of wrestlers' breaststroke, published research, Scientific Journal, Volume I, School of Sports Education for Girls, Helwan University.

\section{7- Elsayed Abd Elmaksood:} (1997) Theory of Athletic Training (Training and Force Physiology), I.4, Al-Kuttab Publishing Center, Cairo.

\section{8- Essam Abdelkhalek:} (2003) Sports Training Theories - Applications, Vol. 11, House of Knowledge, Alexandria.

19- Essam Abdelkhalek: (1992) Sports Training (Theories and Applications), House of Knowledge, Alexandria.

20- Essam Ahmed Helmy; (2015) Training in sports 
activities, Vol. 1, Modern Book Center, Cairo.

\section{1- Essam Mohamed Sakr :} (2020) The impact of functional strength exercises on the strength of the Center's muscles and the effectiveness of some mixed offensive performances by young players in Karate actual conflict, Scientific Journal of Sports Science and Arts, issue of October, Vol. 2, College of Sports Education for Girls, Helwan University.

\section{2- Fabio comana: (2004):}

function training for sports, Human Kinetics: Champaign IL, England.

23- Gardg, Gillk, A., Degerfeldtl: (2000): Mekea ziemethoh and functional training in Back pain rehabilitation. Abriefreview including results from a4 week rehabilitation program me" physical therapy reviews isssn.vol.5,NP:107,115.

\section{4- Gehan Yossef Elsawy;} (2012) Effectiveness of functional power exercises on some physical variables and the level of back kick performance with bounce among taekwondo youth, Scientific Journal of Physical and Sports Education Sciences, 20-21 May, Consta, Romania.

\section{5- Hamdy Abde Lrahaman} Baghdady: (1999) Impact of a program to develop muscle capacity at the performance level of the two skills of twisting and the reverse waist hold of the young wrestlers, an unpublished Master's thesis, Faculty of Physical Education for Boys, Helwan University.

\section{6- Hamed Elbarbary,} Mossaad Hassan Mohamed: (2008) Impact of the use of composed training on the development of muscular capacity and the effective performance of the skill of the reverse center of wrestlers, the Tenth International Scientific Conference on Physical Education and Sports Sciences, the Faculty of Physical Education for Boys, Alexandria University.

27- Ingersoll ,CD, Sewell, jet al: (2008): functional training Vs., Weight training effects on one legged postural sway and elevator strength, journal of athletic training physical educations staring muscle strength, Vol.33ISSU 2,p:71.

28- James ,P,M,.: (1996): Soccer skills for in dividual 
getting and team play, Engle wood cliffs, New York, Jersey. 29- Magdy Ahmed Alewa: (1998) Building a test battery to measure basic skills in wrestling, Ph.D. thesis, Faculty of Physical Education, Zagazig University.

30- Magdy Esmail Elgamal : (2007) Influence of a proposed training program for the force to improve the skill level of the Roman wrestling reverse hold, unpublished Master's thesis, Faculty of Physical Education of Boys, Helwan University.

31- Marius, et al: (2009): Improving the penultimate Step in the Jumping Events, Track Technique, No.112, sum

32- Michael Boyle: (2004): functional Balance training Using a Domed Device, J Spine, 21,pp2640-2650

33- Moataz Mohamed Nageeb Elsayed Elaryan: (2014) Effect of exercises on functional force on some biomechanical variables for the technical performance of triathlon jumpers, unpublished $\mathrm{PhD}$ thesis, Faculty of Physical Education, Mansoura University.

34- Mohamed Elsayed Ashmawy: (2003) The impact of some special exercises on the level of physical and professional performance of the waist hold movement, lifting and curving for wrestlers, Master's thesis, Faculty of Physical Education, Zagazig University.

\section{5- Mohamed Gaber Brekaa,}

Ehab Fawzy Elbedewy: (2004) Casual training Fundamentals - Concepts Applications, Knowledge Establishment, Alexandria.

$\begin{array}{lrr}\text { 36- } & \text { Mohamed } & \text { Hassan } \\ \text { Allawy, Abo } & \text { Elolla }\end{array}$
Abelfatah: (2000) Physiology of Sports Training, Arab Thought House, Cairo.

37- Mohamed Reda Elrooby: (2005) Principles of Training in Sports Wrestling, Mahi Press, Vol.1, Alexandria.

38- Mohamed Sobhy Hassanen, Ahmed Kassry Maanay: (1998) Encyclopedia of Applied Sports Training, Vol.1, Book Center for Publishing, Cairo.

39- Mossa Fahmy Ebraheem , Adel Ali Hassan: (1994) Exercises and Sports Shows, House Of Knowledge, Cairo.

40- Mossaad Ali Mahmoud \& Others.: (1998) The theoretical and practical foundations of the Roman and free wrestling, Alexandria University. 
41- Mossaad Hassan Hedia: (2010) A study on the effect of functional strength training on oxidative stress and some physical variables in wrestling junior.

42- Nabeel Hosny Elshorbgy: (2008) The impact of the use of some development methods for muscle strength on the effectiveness of the performance of the reverse waist hold skill for wrestlers, the 10th International Scientific Conference of Physical Education and Sports Sciences, Faculty of Physical Education for Boys, University of Alexandria.

43- Nabeel Hosny Elshorbgy: (2000) Effect of a proposed program using a twist training device on the level of performance and effectiveness of waist twist skill for advanced wrestlers, PhD thesis, Faculty of Physical Education, Tanta University.

\section{4- Novikov, A;}

Strength training for wrestling, Athlon, Roma

45- Osama Hosny Elshorbgy: (2001) Effect of a proposed training program on the effectiveness of the performance of the skill of the chest of adult wrestlers, unpublished master thesis, Faculty of Physical Education, Tanta University.

46- Ossman Husseen Refaat: (2003) Sport Training Science, Helwan University Press, Cairo 47- Ramy Salama Mahmoud Abdel Hafeez: (2011) A proposed training program for the functional force to improve some physical and skill variables for the football junior, unpublished master's thesis, Faculty of Physical Education for boys in Alharm, Helwan University.

\section{8- Reda Mohamed} Ebraheem (2009): The effectiveness of the functional strength exercises on the strength of the center's muscles and the driving forces and their relation to the level of performance of the skill in the creep back swimming, an unpublished Master's thesis, the Faculty of Physical Education, Zagazig University. 49- Sabry Ali Kotb: (1997) Effect of a proposed program for weightlifting training on the effectiveness of some fall group movements on the two men for adult wrestlers, Master's thesis, Alexandria University. 
50- Salah Mohammed Assran: (1996) A study entitled "The effect of using some of the special force training methods on the effectiveness of the performance of the group of lifting movements up for the second degree wrestlers, Ph.D. thesis, College of Physical Education for Boys, Alexandria University.

51- Salah Mohsen Naga: (2013) Planning entry for sports training duties, Al Hussein Publishing House, Monoufia

\section{2- Talha Hossam Eldin And}

Others. : (1997) Encyclopedia of Sports Training, Arab Thought House, Cairo.

\section{3- Tamer Emad Eldin}

Saeed: (2017) The impact of the use of the Isocentec device on the development of the stem muscle group and the performance of the back kick for the first degree wrestlers, the Scientific Journal of Sports Science and Arts, the Faculty of Sports Education for Girls, Helwan University.

\section{4- Tamer Emad Eldin} Saeed: (2016) The impact of functional strength exercises on the strength of the Center's muscles and their relationship to the level of performance of the change of body level and penetration skills of amateur free wrestlers, the Seventh International Scientific Conference, the School of Sports Education for Girls, Helwan University.

55- Tiana Weiss, and all: (2010): Effect of Functional Resistance Training on Musclar Fitness Outcomes in Young Adults ,J Exerc Sci Fit.

56- Waleed Saleh Abdelgawad Aeed: (2014) Effect of functional strength training on the level of performance of some strength and stability skills on the throat device for a gymnast under 10 years, unpublished master thesis, Faculty of Physical Education, Assiut University.

\section{7- Wassal Abdelwahed} Kortam: (2014) An analytical study of the technical skills of high level players in free wrestling, Master Thesis, Faculty of Physical Education, Sadat City University.

58- Wessam Samy Mohamed: (2016) The Effect of Functional Strength Exercises on the Physiological and physical Variables and the Digital Level of Young swimmers, Master Thesis, 


\section{4}

Faculty of Physical Education, Kafr El Sheikh University.

59- Westcott W: (1995):

Strength fitness physiological principles and training techniques 4th ed., brown and benchmark publishers

60- Yasumura ST, and all:

(2000): Characteristics of functional training and effects on physical activities of daily living , Nippon Koshu EiseiZasshi . Sep; Vol. 47(9):792-800

61- Zaki Mohammed

Mohammed Hassan: (2004)

Cross Training Is a Modern trend in sports training, Egyptian Library for Publishing and Distribution, Alexandria.

62- https://ar.m.wikipedia .org/wiki/Dubuque. IQula. 